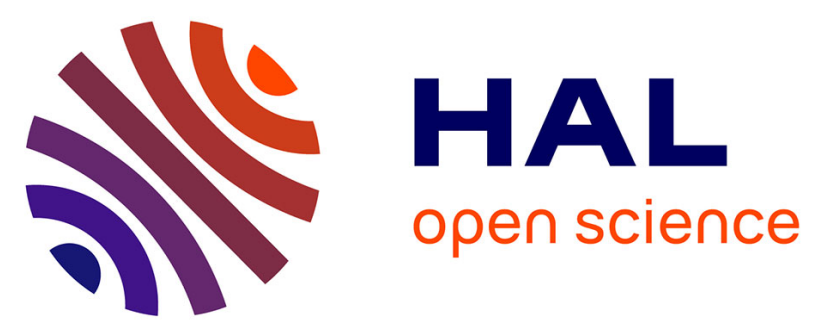

\title{
Iron speciation at the riverbank surface in wetland and potential impact on the mobility of trace metals
}

\author{
Gildas Ratié, D. Vantelon, Elaheh Lotfi Kalahroodi, I. Bihannic,
} Anne-Catherine Pierson-Wickmann, Mélanie Davranche

\section{- To cite this version:}

Gildas Ratié, D. Vantelon, Elaheh Lotfi Kalahroodi, I. Bihannic, Anne-Catherine Pierson-Wickmann, et al.. Iron speciation at the riverbank surface in wetland and potential impact on the mobility of trace metals. Science of the Total Environment, 2019, 651 (1), pp.443-455. 10.1016/j.scitotenv.2018.09.143 . insu-01872381

\section{HAL Id: insu-01872381 \\ https://hal-insu.archives-ouvertes.fr/insu-01872381}

Submitted on 12 Sep 2018

HAL is a multi-disciplinary open access archive for the deposit and dissemination of scientific research documents, whether they are published or not. The documents may come from teaching and research institutions in France or abroad, or from public or private research centers.
L'archive ouverte pluridisciplinaire HAL, est destinée au dépôt et à la diffusion de documents scientifiques de niveau recherche, publiés ou non, émanant des établissements d'enseignement et de recherche français ou étrangers, des laboratoires publics ou privés. 


\section{Accepted Manuscript}

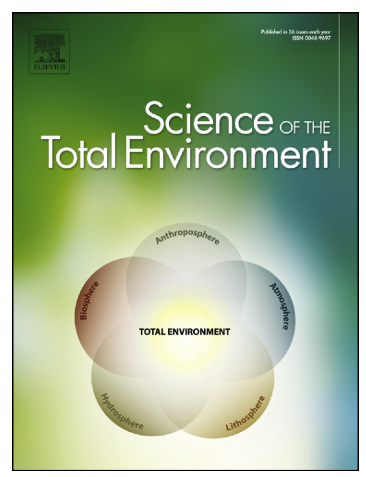

Iron speciation at the riverbank surface in wetland and potential impact on the mobility of trace metals

G. Ratié, D. Vantelon, E. Lotfi Kalahroodi, I. Bihannic, A.C. Pierson-Wickmann, M. Davranche

PII: $\quad$ S0048-9697(18)33587-3

DOI: $\quad$ doi:10.1016/j.scitotenv.2018.09.143

Reference: $\quad$ STOTEN 28647

To appear in: $\quad$ Science of the Total Environment

Received date: $\quad 25$ June 2018

Revised date: $\quad 7$ September 2018

Accepted date: $\quad 10$ September 2018

Please cite this article as: G. Ratié, D. Vantelon, E. Lotfi Kalahroodi, I. Bihannic, A.C. Pierson-Wickmann, M. Davranche, Iron speciation at the riverbank surface in wetland and potential impact on the mobility of trace metals. Stoten (2018), doi:10.1016/ j.scitotenv.2018.09.143

This is a PDF file of an unedited manuscript that has been accepted for publication. As a service to our customers we are providing this early version of the manuscript. The manuscript will undergo copyediting, typesetting, and review of the resulting proof before it is published in its final form. Please note that during the production process errors may be discovered which could affect the content, and all legal disclaimers that apply to the journal pertain. 


\section{Iron speciation at the riverbank surface in wetland and potential impact on the mobility of trace metals}

G. Ratie ${ }^{a}$, D. Vantelon ${ }^{a}$, E. Lotfi Kalahroodi ${ }^{b}$, I. Bihannic $^{c}$, A.C. Pierson-Wickmann ${ }^{b}$, M.

\section{Davranche $^{b}$}

${ }^{a}$ SOLEIL synchrotron, L'orme des merisiers, Saint Aubin BP48, 91192, Gif-sur-Yvette Cedex, France

${ }^{b}$ Géosciences Rennes, UMR 6118, Université de Rennes 1, Campus de Beaulieu, 35042, Rennes Cedex, France

${ }^{c}$ Université de Lorraine, CNRS, LIEC, F-54000 Nancy, France

\section{Keywords}

Riverbank, Fe oxyhydroxides, Fe solid speciation, XANES, Trace metal mobility, Wetland 


\section{Abstract}

Fe oxyhydroxides in riverbanks and their high binding capacity can be used to hypothesize that riverbanks may act as a "biogeochemical filter" between wetlands and rivers and may constitute a major mechanism in the trapping and flux regulation of chemical elements. Until now, the properties of Fe minerals have been very poorly described in riverbanks. The goals of the present work are to identify Fe speciation in riverbanks where ferric deposits are observed and to determine their impact on the metal behavior (As, $\mathrm{Co}, \mathrm{Cu}, \mathrm{Ni}, \mathrm{Pb}, \mathrm{Zn}$, etc.).

At the surface, Fe speciation is mainly composed of small poorly crystalline Fe phases, i.e. ferrihydrite $(\sim 30 \%)$, Fe-OM associations $(\sim 40 \%)$ as well as crystalline Fe phases, i.e. goethite $(\sim 35 \%)$. At the subsurface, the Fe distribution is dominated by goethite $(\sim 35 \%)$ and Fe-mica $(\sim 35 \%)$, the proportion of which increases at the expense of ferrihydrite and the Fe-OM associations.

At the riverbank surface, ferrihydrite and the Fe-OM associations are therefore the main Fe hosting phases in response to (i) the fast $\mathrm{Fe}$ (II) oxidation induced by the presence of $\mathrm{O}_{2}$ and (ii) the high amount of $\mathrm{OM}$ favoring the formation of nano-phases bound to $\mathrm{OM}(\mathrm{Fe}$ monomers, polymers and nanoparticles) and preventing mineralogical transformation (ferrihydrite into goethite).

During the high-water level period (high flow), a strong erosion of the riverbank transfers these ferric deposits into the river. However, the physicochemical parameters of the river $(\mathrm{pH}$ 6.6-7.6 and continuous oxic conditions) do not promote the dissolution of Fe oxyhydroxides and OM. Ferric deposits and the associated trace metals are therefore maintained as colloids/particles and are exported to the outlet. All of the results presented here demonstrate that the ferric deposits trap metals on a seasonal basis and are therefore a key factor in the mobilization of metals during riverbank erosion by river flow.

\section{Introduction}

In the watershed, the riverbanks are strategic zones between the soil, groundwater, hyporheic zone and river. In wetland, reduction periods occur promoting a strong solubilization of chemical due to the 
water saturation in soil. Reduced water is charged in chemical and drained by river that is under oxic conditions exhibiting high Eh values (directly in contact with $\mathrm{O}_{2}$ from atmosphere) (e.g. Dia et al., 2000; Olivié-Lauquet et al., 2001; Grybos et al., 2007; Kerr et al., 2008; Schulz-Zunkel and Krueger, 2009). There is also a formation of a strongly reactive redox interface in riverbank. The redox potential (Eh) and $\mathrm{pH}$ variations, as well as the amount of organic matter $(\mathrm{OM})$ and both $\mathrm{Fe}$ and $\mathrm{Mn}$ oxyhydroxides solubilization/precipitation control the processes that drive the mobility of the associated chemical elements (e.g. McKenzie, 1980; Dzombak and Morel, 1990; Lee et al., 2002; Grybos et al., 2007; Borch et al., 2009, Du Laing et al., 2009). Organic matter and Fe/Mn oxyhydroxides are well-known scavengers of chemical elements because of their high surface-sorption capacity (e.g. McKenzie, 1980; Buffle, 1988; Mustafa and Haq, 1988; Benedetti et al., 1996; Trivedi and Axe, 2001; Grybos et al., 2007; Hassellöv and von der Kammer, 2008; Lynch et al., 2014). In wetlands, under reducing conditions, Fe oxyhydroxides are dissolved by mechanisms that are largely catalyzed by bacteria, releasing Fe(II) in solution and associated elements such as metals or metal-OM complexes (Francis and Dodge, 1990; Chuan et al., 1996; Charlatchka and Cambier, 2000; Dia et al. 2000; Zachara et al., 2001; Davranche et al., 2003; Grybos et al., 2007). Iron(II) released in solution may therefore precipitate as solid $\mathrm{Fe}(\mathrm{III})$ in response to the $\mathrm{O}_{2}$ diffusion in the riverbank porosity.

The variability in physicochemical conditions (temperature, redox potential, $\mathrm{pH}, \mathrm{O}_{2}, \mathrm{CO}_{2}$, nutrients) produces a wide range of $\mathrm{Fe}$ oxyhydroxides (i.e. goethite, ferrihydrite, lepidocrocite, hematite, maghemite, etc.) with different morphologies, surface areas and particle sizes (e.g. Roden, 2003; Taylor and Konhauser, 2011). Goethite $(\alpha-\mathrm{FeOOH})$ is the most common $\mathrm{Fe}$ oxyhydroxide in environment with respect to its high thermodynamic stability under ambient conditions (Cornell and Schwertmann, 2003; Navrotsky et al., 2008). Ferrihydrite, a hydrated semi-crystalline material $\left(\mathrm{Fe}_{5}(\mathrm{OH})_{8} \cdot 4 \mathrm{H}_{2} \mathrm{O}\right)$ and lepidocrocite $(\gamma-\mathrm{FeOOH})$ are also known to exist in wetland environments (e.g. Gault et al., 2012; Guénet et al., 2016). Ferrihydrite is generally the result of the fast hydrolysis of $\mathrm{Fe}(\mathrm{III})$ in a poorly crystalline structure, while lepidocrocite develops through the oxidation of $\mathrm{Fe}(\mathrm{II})$ from the structure of the minerals (e.g. biotite) or through intermediary mineral transformation, e.g. green rust (Tarzi and Protz, 1978; Schwertmann and Fechter, 1994; Vodyanitskii, 2010). Furthermore, 
the occasional formation of lepidocrocite in pure Fe(III) systems has been reported (Fordham, 1970) and Guénet et al. (2016) evidenced the formation of nano-lepidocrocite and small Fe nano-oxides bound to $\mathrm{OM}$ in a riparian wetland.

Both the presence of such Fe oxyhydroxides at the riverbank surface and their high binding capacity allow hypothesizing that riverbanks may act as a "biogeochemical filter" between wetlands and rivers which could be a major mechanism in the trapping and flux regulation of chemical elements. Some studies have shown the impacts of riverbank sediments on the improvement in water quality in alluvial aquifers (e.g. Bourg et al., 1989; Du Laing et al., 2007), on the redox trapping of As or Zn (e.g. Datta et al., 2009; Stahl et al., 2016; Lynch et al., 2017), or on the distribution of elements ( $\mathrm{Zn}$ and $\mathrm{Fe}$ ) along vertical redox gradients of floodplain soil profiles (Shaheen and Rinklebe, 2014; Chen et al., 2017). However, the properties of Fe minerals are very poorly described in riverbanks. Redox alternations influence the composition and properties of the ferric deposits that can be formed along riverbanks. As a result, it is crucial to better characterize this strategic interface in order to predict the speciation and transport of metals, nutrients or organic compounds. For this purpose, riverbank samples were collected in the Mercy wetland at Naizin (Morbihan region, France). Iron-bearing phases were identified using complementary techniques: X-ray diffraction (XRD) to identifiy Fe oxyhydroxides crystalline structures, scanning electron microscopy (SEM) to unravel poorly crystalline structures and associations with OM and X-ray absorption spectroscopy (XAS) to characterize the Fe solid-phases speciation.

\section{Materials and methods}

\subsection{Sample location and sampling}

Riverbank samples were collected from the Mercy riparian wetland of Kervidy-Naizin located in Brittany, Western France (Figure 1). Numerous hydrological and biogeochemical studies have characterized this area over the past 20 years (ORE AgrHyS). Since redox cycles involving Fe have been highlighted in this wetland (e.g. Dia et al., 2000; Olivié-Lauquet et al., 2001; Grybos et al., 2007), this catchment is particularly suitable for studying solid-phase Fe speciation. The Mercy 
riparian wetland is regularly altered by drying (in summer) and flooding (in winter) conditions (Lambert et al., 2013; Figure EA-4). Soils are developed in a colluvio-alluvial formation (Bourrié et al., 1999). The soil displays four horizons (Figure 1d): (1) from 0 to $10 \mathrm{~cm}$, an organic horizon (O); (2) from 10 to $30 \mathrm{~cm}$, an organo-mineral horizon (Ah); (3) from 30 to $40 \mathrm{~cm}$, an albic horizon (Ga); (4) less than $40 \mathrm{~cm}$, redoxic horizon (g). Soils in the Mercy wetland are considered as organo-mineral soils mainly dominated by clay (42\%), quartz (30\%) and Fe oxyhydroxides (3.5\%). The clay fraction is composed of kaolinite, smectite, mica, hydroxyl-aluminous, vermiculite and interstratified minerals (Pellerin and Van Vliet-Lanoë, 1998). Bourrié et al. (1999) demonstrated the presence of green rusts in these hydromorphic soils between the redoxic horizon and the schistose saprolite.

Samples were collected in December 2016. However, there was no significant water flow in the stream bed. All samples were therefore collected under oxic conditions. Samples were collected at the riverbank surface (Figure 1d), where ferric deposits are observed over a length of 20-30m (Surface samples: P1 0-5, P1 5-10, P2A, P2B and P3). Riverbank is in permanence under oxic conditions. The water level bellows the ferric deposit allowing a supply of $\mathrm{O}_{2}$ regardless the atmosphere and the water is always under oxic conditions (Figure EA-4). P1 samples include the organic horizon. P2A and P2B include the albic horizon and P3 is a peculiar sample corresponding to a small amount of the observed ferric deposit (Figure 1c). The ferric deposit is essentially developed on the surface of the albic horizon (Figure 1c) making of $\mathrm{P} 2 \mathrm{~A}$ and $\mathrm{P} 2 \mathrm{~B}$ the most suitable to represent Fe deposits at the riverbank surface. A profile was also collected below the riverbank surface (horizontal thickness of $\sim 10 \mathrm{~cm}$, subsurface samples) in three horizons: Ah (P4A), Ga (P4B1 and P4B2) and g (P4C) (Figures 1b and d). Samples were stored in a plastic bag until the laboratory and they were dried at ambient temperature. Then, samples were sieved at $2 \mathrm{~mm}$ (bulk fraction). This fraction was disaggregated using an ultrasonic tub and then divided into a fine fraction $(<50 \mu \mathrm{m})$ by dry sieving and a clay fraction $(<4 \mu \mathrm{m})$ using the sedimentation technique according to Stokes' law. The amount of P3 and P2A samples did not allow performing size partitioning. Clay fraction separation was thus performed only onto P1 0-5, P1 5-10, P2B, P4A, P4B1 and P4C. 


\subsection{Chemical and mineralogical analysis}

The chemical composition of both the $<2 \mathrm{~mm}$ and $<50 \mu \mathrm{m}$ fractions was determined at the Service d'Analyse des Roches et des Minéraux (SARM, France) and all analytical methods were subject to QC/QA 142 procedures using certified reference materials (Carignan et al., 2001). After sample fusion with $\mathrm{LiBO}_{2}$ and acid digestion with $\mathrm{HNO}_{3}$, the major elements were determined by Inductively Coupled Plasma-Optical Emission Spectrometry (ICP-OES ; iCap6500 ThermoFisher) and the trace elements were measured by Inductively Coupled Plasma-Mass Spectrometry (ICP-MS ; iCapQ Thermofisher) following the protocol described in Carignan et al. (2001). The Organic Carbon (OC) and total sulfur $\left(\mathrm{S}_{\mathrm{tot}}\right)$ contents were determined using an oxygen combustion method with a CS analyzer (Leco SC144 DRPC). The chemical composition of the $<4 \mu \mathrm{m}$ size fraction was carried out using an Agilent 7700x ICP-MS at Geosciences Rennes (University of Rennes1) following the protocol described in Guénet et al. (2016). All results for chemical composition are reported in Table EA-1.

The mineralogical composition (major and well crystallized minerals) was determined by X-Ray Diffraction (XRD), using a D2phaser Bruker at Soleil Synchrotron and a D8 Bruker at the Laboratory Interdisciplinaire des Environnements Continentaux (LIEC, France). The D2phaser was used for the finely crushed powders of the $<2 \mathrm{~mm}$ size fraction and the fine fraction $(<50 \mu \mathrm{m})$. The diffractometer used Ni-filtered $\mathrm{Cu}-\mathrm{K} \alpha$ radiation with an operating power of $300 \mathrm{~W}$. The step-size of the acquisitions was $0.020^{\circ} 2 \theta$ with a counting time of $2 \mathrm{~s}$ per step over a scanning range of 5 to $80^{\circ} 2 \theta$. The D8 was used for the clay fractions $(<4 \mu \mathrm{m})$ with $\mathrm{Co}-\mathrm{K} \alpha$ radiation. The diffractometer is equipped with a position sensitive detector (PSD). The step-size of the acquisitions was $0.034^{\circ} 2 \theta$ with a counting time of $3 \mathrm{~s}$ per step over a scanning range of 2 to $402 \theta$. Clay fraction was then deposited on three glass slides to obtain oriented preparations. XRD patterns were then recorded after air-drying for the first slide, saturation overnight with ethylene glycol in vapor phase or heating at $550^{\circ} \mathrm{C}$ during 4 hours.

In order to identify poorly crystalline structure or micro/nanometric size and the phases associated with OM, backscattered electron images of the samples were obtained at the CMEBA analytical platform (University of Rennes 1, France) using a scanning electron microscope / energy dispersive X- 
ray spectroscopy (SEM/EDS) "JEOL JSM 7100 F EDS EBSD Oxford" operating at a beam voltage of $1 \mathrm{kV}$ for a resolution of $2 \mathrm{~nm}$, and a beam current of $1 \mathrm{pA}$. The elemental spectra were determined using EDS (X-Max 50mm² Oxford instruments AZtecEnergy). Samples were deposited on carbon film or embedded in epoxy resin (Epofix 1232, Electron Microscopy Sciences).

\subsection{X-ray absorption spectroscopy (XAS)}

\subsubsection{Data collection}

The Fe K-edge X-ray Absorption Near Edge Structure (XANES) spectra were collected on the LUCIA beamline (SOLEIL Synchrotron) (Flank et al., 2006; Vantelon et al., 2016). The references and samples were prepared as pellets of finely ground and homogenized powder with cellulose. Clay fractions were deposited in wet form on a copper plate and were then air dried before analysis. The data were collected under vacuum $\left(10^{-2}\right.$ mbar) using a Si (311) double-crystal monochromator with a beam size of $2 * 2 \mathrm{~mm}^{2}$. The monochromator was calibrated by setting the first inflexion point of a $\mathrm{Fe}$ metallic foil XANES to $7112 \mathrm{eV}$. Spectra were collected in transmission (using a Si diode) and fluorescence modes (using a Bruker SDD mono-element $60 \mathrm{~mm}^{2}$ ). Two or three spectra were collected over the 7050-7500 eV energy range with $2 \mathrm{eV}$ steps before the edge, $0.1 \mathrm{eV}$ steps in the pre-edge region, $0.2 \mathrm{eV}$ steps in the edge region, $1 \mathrm{eV}$ step after the edge region and $2 \mathrm{eV}$ steps for the rest of the spectrum. The counting time was set to $1 \mathrm{~s}$ per point.

\subsubsection{XAS data analysis}

Iron XANES spectra were extracted using the Athena software (Ravel and Newville, 2005). Normalized spectra were obtained by fitting the pre-edge region with a linear function and the postedge region with a quadratic polynomial function. All of the spectra from each sample were merged. The energy resolution of a $\mathrm{Si}$ (311) monochromator allows us to determine the relative $\mathrm{Fe}$ solid speciation by Linear Combination Fits (LCFs) using model compounds. LCFs were performed on the normalized XANES spectra in the 7108-7158 eV energy range, not forcing the weights to sum up to 1 , using the ATHENA software. A reduced $\chi^{2}$ was used to characterize the fit "quality". 
The selection of reference compounds (i.e. Fe-bearing phases) was based on XRD results, SEM investigations and past studies (e.g. Bourrié et al., 1999; Dia et al., 2000; Grybos et al., 2007; Guénet et al., 2016). Therefore, a set of Fe oxyhydroxides such as ferrihydrite, lepidocrocite, goethite and hematite (synthetized at SOLEIL synchrotron and the Geosciences Rennes laboratory) as well as a set of phyllosilicates containing Fe smectite (Swy-2), illite (from CMS) muscovite (from Bihar) and biotite were selected. Additionally, Fe-OM associations were synthesized at a ratio of $0.4 \mathrm{Fe} / \mathrm{OC}$ (wt/wt) using leonardite humic acid from IHSS $(\mathrm{C}=63.81 \%, \mathrm{O}=31.27 \%, \mathrm{H}=3.70 \%$ and $\mathrm{N}=1.23 \%)$ following the procedure described in Guénet et al. (2017). All references were measured in the same conditions as the samples.

\subsection{Principal component analysis}

Multivariate analysis, including principal component analysis (PCA), is largely used to analyze the structure of large datasets. The main goal of this technique is to offer a better visualization of the metal content loads in association with the Fe and OM contents. The rows of the starting data matrix for PCA analysis represent the different samples, their size-partition and their location (i.e. 15 observations: surface and subsurface riverbanks, $<2 \mathrm{~mm}$ and $<50 \mu \mathrm{m}$ ) and the columns represent the variables, i.e. the elemental contents (29 variables included major constituents, metals, REE highest concentrated and some element of the geochemical background: OC, $\mathrm{S}_{\mathrm{tot}}, \mathrm{Si}, \mathrm{Al}, \mathrm{Fe}, \mathrm{Mg}, \mathrm{Ca}, \mathrm{Na}, \mathrm{K}$, Ti, As, Ba, Cd, Ce, Co, Cr, Cs, Cu, Eu, La, Nd, Ni, Pb, Sb, Sr, U, V, Zn and Zr). As the <4 $\mu \mathrm{m}$ fraction was extracted to highlight the very small amount of Fe oxyhydroxides in the riverbank samples, it is not well suited and thus not used to prospect the correlation between the elements. PCA analyses were performed using Pearson's correlation (Table EA-2) with the XLSTAT software (Addinsoft). P-values were calculated to indicate significance at either the $1 \%$ or $5 \%$ level (Table EA-2).

\section{Results}

\subsection{Elemental content gradient in the riverbank}

Riverbanks from the Mercy riparian wetland of Kervidy-Naizin present a very different aspect in terms of color (gray to orange) and texture (organic, sand, clay) in the surface where ferric deposits are 
observed (Figure 1b and 1c). The composition of the major, minor and trace elements of the surface and subsurface riverbank sample are presented in Table EA-1. The metal behavior in the riverbank is subject to fluctuations at the oxic/anoxic interface in response to the frequency and the duration of flood (Lynch et al., 2014). This leads to study As, Cd, Co, Cr, $\mathrm{Cu}, \mathrm{Ni}, \mathrm{Pb} \mathrm{Sb}, \mathrm{Zn}$ and $\Sigma$ REE due to their interaction with metal bearing phases ( such as $\mathrm{OM}$ and $\mathrm{Fe}$ oxyhydroxides). Those selected elements are reported in Figure 2 to better visualize their distribution in the various size fractions.

\subsubsection{Bulk fraction $(<2 \mathrm{~mm})$}

The ferric deposit P3 exhibits a very high Fe content (6.5 wt\%) as well as high contents of As (60 mg $\left.\mathrm{kg}^{-1}\right), \mathrm{Co}\left(147 \mathrm{mg} \mathrm{kg}^{-1}\right), \mathrm{Cu}\left(23 \mathrm{mg} \mathrm{kg}^{-1}\right), \mathrm{Ni}\left(49 \mathrm{mg} \mathrm{kg}^{-1}\right), \mathrm{Pb}\left(35 \mathrm{mg} \mathrm{kg}^{-1}\right)$. The riverbank samples composition is dominated by $\mathrm{Si}, \mathrm{Al}$ and Fe contents (28-36 wt \%; $2-3 \mathrm{wt} \% ; 1-4 \mathrm{wt} \%$, respectively). An increase in the iron content is observed from the subsurface ( 1wt\%) to the surface (up to $4 \mathrm{wt} \%$ ). Arsenic, $\mathrm{Co}, \mathrm{Cu}, \mathrm{Ni}, \mathrm{Pb}$ and $\mathrm{Zn}$ are also systematically enriched on the riverbank surface reaching 39 $\mathrm{mg} \mathrm{kg}{ }^{-1}, 36 \mathrm{mg} \mathrm{kg}^{-1}, 43 \mathrm{mg} \mathrm{kg}^{-1}, 36 \mathrm{mg} \mathrm{kg}^{-1}, 40 \mathrm{mg} \mathrm{kg}^{-1}$ and $68 \mathrm{mg} \mathrm{kg}^{-1}$, respectively. The $\mathrm{Fe}, \mathrm{As}, \mathrm{Co}$, $\mathrm{Cu}, \mathrm{Ni}, \mathrm{Pb}$ and $\mathrm{Zn}$ contents in wetland soils are largely lower than in the riverbank samples (Grybos et al., 2007; Davranche et al., 2013). Conversely, no differences can be observed for the Cr contents between the surface and subsurface of the riverbanks. The cadmium content is low and the Sb content presents very small variations. The organic carbon (OC) contents vary from 0.6 to $3.9 \mathrm{wt} \%$, exhibiting the highest contents for the samples collected in the organic horizon (P1 samples). The samples are relatively $\mathrm{S}_{\text {tot }}$ low (from 0.03 to $0.07 \mathrm{wt} \%$ ).

\subsection{2. $<50 \mu \mathrm{m}$ size fraction}

The riverbank samples composition is dominated by Si, Al and Fe (31-35 wt\%; 2-4 wt\%; 1-3 wt\%, respectively). However, at the surface, the $\mathrm{Fe}$ and metals contents are lower than in the $<2 \mathrm{~mm}$ fraction (maximum content for Fe: $3 \mathrm{wt} \%$, As: $29 \mathrm{mg} \mathrm{kg}^{-1}$, Co: $14 \mathrm{mg} \mathrm{kg}^{-1}, \mathrm{Cu}: 27 \mathrm{mg} \mathrm{kg}^{-1}$, Ni: $33 \mathrm{mg}$ $\left.\mathrm{kg}^{-1}, \mathrm{~Pb}: 33 \mathrm{mg} \mathrm{kg}^{-1}, \mathrm{Zn}: 66 \mathrm{mg} \mathrm{kg}^{-1}\right)$. The same enrichment in $\mathrm{Fe}, \mathrm{As}, \mathrm{Co}, \mathrm{Cu}, \mathrm{Ni}, \mathrm{Pb}$ and $\mathrm{Zn}$ is observed at the riverbank surface. The $\sum \mathrm{REE}$ and $\mathrm{Cr}$ contents are higher in the $<50 \mu \mathrm{m}$ fraction than in the bulk. 


\subsection{3. $<4 \mu \mathrm{m}$ size fraction}

The accumulation of metal observed in the bulk and in the $<50 \mu \mathrm{m}$ fraction between the subsurface and surface is less pronounced for the $<4 \mu \mathrm{m}$ fraction. The chemical composition of the $<4 \mu \mathrm{m}$ fraction exhibits the highest Fe content for P2B (the most suitable sample to represent Fe deposits at the riverbank surface) and P4C (redoxic horizon). Sample P2B exhibits up to 17 wt $\%$ of Fe with very high contents of As $\left(88 \mathrm{mg} \mathrm{kg}^{-1}\right), \mathrm{Co}\left(27 \mathrm{mg} \mathrm{kg}^{-1}\right), \mathrm{Cu}\left(68 \mathrm{mg} \mathrm{kg}^{-1}\right), \mathrm{Ni}\left(77 \mathrm{mg} \mathrm{kg}^{-1}\right), \mathrm{Pb}\left(51 \mathrm{mg} \mathrm{kg}^{-1}\right)$ and $\mathrm{Zn}\left(152 \mathrm{mg} \mathrm{kg}^{-1}\right)$, as compared to the other riverbank surface samples. Sample P4C also shows very high contents of Fe (9 wt $\%)$, As $\left(40 \mathrm{mg} \mathrm{kg}^{-1}\right), \mathrm{Co}\left(30 \mathrm{mg} \mathrm{kg}^{-1}\right), \mathrm{Cu}\left(51 \mathrm{mg} \mathrm{kg}^{-1}\right), \mathrm{Ni}\left(98 \mathrm{mg} \mathrm{kg}^{-1}\right)$, $\mathrm{Pb}\left(62 \mathrm{mg} \mathrm{kg}^{-1}\right)$ and $\mathrm{Zn}\left(148 \mathrm{mg} \mathrm{kg}^{-1}\right)$.

\subsection{Element correlation by PCA analysis}

A statistical analysis was performed in order to discern the relationship between the distribution of $\mathrm{Fe}$ and the other elements. Figure 3 displays a bi-plot representing the variable correlations with respect to the first and second principal components. The first component (F1) accounts for roughly $37 \%$ of the total variance and the second component (F2) explains approximately $35 \%$ of the whole dataset variance for the $<2 \mathrm{~mm}$ and $<50 \mu \mathrm{m}$ size fractions of the riverbank samples.

All of the variables except Si are positively correlated with the first component F1. The second component discriminates a "metal group" correlated with $\mathrm{Fe}, \mathrm{OC}$ and $\mathrm{S}_{\mathrm{tot}}$ : $\mathrm{As}, \mathrm{Cd}, \mathrm{Co}, \mathrm{Cu}, \mathrm{Cd}, \mathrm{Ni}, \mathrm{Pb}$, $\mathrm{Sb}$ and $\mathrm{Zn}$. The Pearson correlation matrix exhibits the highest Pearson factor (PF) with Fe for As (0.97, $\mathrm{p}$ value $<0.01), \mathrm{Co}(0.69, \mathrm{p}$ value $<0.01), \mathrm{Cu}(0.75, \mathrm{p}$ value $<0.01), \mathrm{Ni}(0.81, \mathrm{p}$ value $<0.01)$ and $\mathrm{Sb}(0.82$, p value < 0.01$)$, while OC and $\mathrm{S}_{\text {tot }}$ present the highest Pearson factor for $\mathrm{Cd}(0.78-0.83, \mathrm{p}$ values < 0.01), $\mathrm{Pb}(0.75-0.80, \mathrm{p}$ values < 0.01$)$ and $\mathrm{Zn}(0.64-0.72, \mathrm{p}$ values < 0.01$)$ (Table EA-2). The combination of the F1 and F2 PCA components can also be used to differentiate two other groups: Al, $\mathrm{Ba}, \mathrm{Cs}, \mathrm{Cr}, \mathrm{K}, \mathrm{Mg}, \mathrm{Na}, \mathrm{Ti}, \mathrm{Sr}$ and $\mathrm{Zr}$ on one side, representing the geochemical background of the wetland soil, and $\mathrm{Ce}, \mathrm{La}, \mathrm{Nd}, \mathrm{Eu}, \mathrm{U}$ and $\mathrm{V}$ on the other side, and which is between the geochemical background and the element correlated with the absorbing phases (Fe oxyhydroxides and OM). 


\subsection{Mineralogical composition}

\subsubsection{XRD pattern}

X-ray diffraction patterns of the riverbank bulk samples are largely dominated by quartz and clay minerals (data not shown). XRD measurements were then performed on the $<4 \mu \mathrm{m}$ fractions in order to identify the fine mineralogy and the Fe oxyhydroxides potentially identifiable by XRD (goethite, lepidocrocite, hematite, maghemite, etc.). The patterns are shown in Figure EA-1. Additionally, the XRD patterns were recorded after glycolated and heated treatment on $<4 \mu \mathrm{m}$ fractions to evidence goethite and phyllosilicates. An example is given in Figure 4 (P2B sample).

The XRD patterns show the presence of phyllosilicates such as chlorite, vermiculite, mica and kaolinite. Specific peaks of muscovite and vermiculite are superimposed in the heated diffractogram due to the shift of the vermiculite peak during heating (10.01 $\AA$, $5.00 \AA$ and $3.32 \AA$ ). Some quartz residues are also detected (characteristic peaks at $3.34 \AA$, $4.27 \AA$ ).

Goethite is the only Fe oxyhydroxide identified with a distinct peak at $4.19 \AA$ in the XRD patterns. Other Fe oxyhydroxides are expected to be present in these riverbank samples, however due to their poorly crystalline structure (e.g. ferrihydrite) or their possible micro/nanometric size it is not possible to identify them. No peak at $6.23 \AA$ corresponding to lepidocrocite (e.g. Tarzi and Protz, 1978; Ross et al., 1979) is observed. However, in this studied wetland, Guénet et al. (2016) demonstrated that Fe is present as nano-lepidocrocite, small Fe clusters and Fe monomers bound to $\mathrm{OM}$ in response to a slow oxidation kinetic and to the presence of a large amount of OM.

\subsubsection{SEM observations}

Scanning electron microscopy was used to obtain images of the Fe-bearing phases. They were detected according to their higher electron density and elemental composition using EDS analysis. We focused on three samples (P3, P2B and P4C) due to their high Fe content. The samples exhibit different structures of $\mathrm{Fe}$ oxyhydroxides. Figure 5a represents an aggregate of crystalline Fe oxyhydroxides with the star shape of goethite structure (Cornell et al., 1983). Their apparent sizes are smaller than 4-5 
$\mu \mathrm{m}$ in length and their Fe contents reach up to mean value of $58 \mathrm{wt} \%(\mathrm{n}=3)$. Fine star-shaped structures, less enriched in Fe (50 wt \%), can be observed in Figure 5b. An external layer composed of $\mathrm{Fe}(49 \mathrm{wt} \%)$ surrounds the star aggregate.

Figure $5 \mathrm{c}$ represents an aggregate of numerous spheroid particles. Figure $5 \mathrm{~d}$ can be used to estimate the size of these non-crystalline nanoparticles, ranging from $100 \mathrm{~nm}$ to $500 \mathrm{~nm}$ in size. These nanoparticles are comprised of $\mathrm{Fe}$ at a two times lower content (29 and $32 \mathrm{wt} \%$ ) than that found in the structures observed in Figures 5a and 5b. Figure 5e shows a very fine-ordered layer comprised of Fe (48 wt \%). It is 6-7 $\mu \mathrm{m}$ wide and at least $30-40 \mu \mathrm{m}$ long. It is delimitated by an external layer made up of $45 \mathrm{wt} \%$ of Fe. Figure $5 \mathrm{f}$ highlights a large aggregate up to $80 \mu \mathrm{m}$ composed of $70 \mathrm{wt} \%$ of $\mathrm{Fe}$. Figure $5 \mathrm{~g}$ shows the clay matrix, where the Fe oxide particles are surrounded by clay aggregates ([Fe] $=13 \mathrm{wt} \%$ ). At least five different Fe oxyhydroxide structures (stars, fine layers, spheroid particles and two types of large aggregates) are observed. However, only goethite can be clearly identified based on its star shape (Figures 5a and 5b).

\subsection{Solid Fe speciation}

\subsubsection{Fe K-edge XANES data}

The Fe K-edge XANES spectra and LCF results are given in Figure 6. The spectra of the reference compounds used for the LCF are plotted in Figure EA-2. The numerical results of the LCF are reported in Table EA-3. The spectra exhibit a pre-edge, followed by a white line which is followed by a shoulder. The position of the pre-edge depends on the redox state of $\mathrm{Fe}$ in the Fe-bearing minerals (Wilke et al., 2001). All of the samples present their pre-edge at $7115 \mathrm{eV}$ indicating that $\mathrm{Fe}(\mathrm{III})$ is the main oxidation state in all samples in accordance with the oxic conditions occurring in the riverbank during the low water level period. The analysis of the XANES region reveals pronounced differences among the samples. The white line presents a maximum that varies from 7131 to $7133 \mathrm{eV}$. A width enlargement for the surface samples and a refinement for the subsurface samples is observed. The shoulder is also more or less intense at $\sim 7150 \mathrm{eV}$. The good quality of the LCF ( $\chi^{2}$ reduced), which varies from $0.910^{-5}$ to $5.610^{-5}$, is used to discuss Fe speciation in riverbank samples. 


\subsubsection{At the riverbank surface}

In the bulk fraction, $\mathrm{Fe}$ is mainly hosted by goethite, ferrihydrite and $\mathrm{Fe}-\mathrm{OM}(23-36 \%, 16-31 \%$ and $29-41 \%$, respectively). Iron speciation in the P3 sample exclusively representing the Fe crust is strongly dominated by Fe oxyhydroxides and Fe-OM associations. Lepidocrocite also appears as a Febearing phase according to the LCF results. However, given that the proportion is less than 7\%, it may not be significant. The LCF results identify muscovite, i.e. a mica mineral type, as a Fe host phase (Femica) with up to $21 \%$ of $\mathrm{Fe}$ in sample $\mathrm{P} 15-10$ in contact with the O/Ah horizons. For the other samples, Fe hosted by muscovite does not exceed $14 \%$. The amount of Fe hosted by biotite is very low (Table EA-3) and within the error bar $( \pm 10 \%)$. However, in such context find Fe in biotite is possible, but we did not over-interpret the presence of biotite.

In the fine fraction $(<50 \mu \mathrm{m}), \mathrm{Fe}$ is mainly hosted by goethite $(21-34 \%)$, ferrihydrite $(13-40 \%)$ and Fe-OM (20-39\%). Iron speciation in P2B (the most suitable sample for Fe deposits at the riverbank surface, Figure 1) is characterized by the highest proportion of goethite (34\%), ferrihydrite (40\%) and Fe-OM associations (20\%).

\subsubsection{At the riverbank subsurface}

In the bulk fraction, $\mathrm{Fe}$ is mainly hosted by goethite (23-36\%) and muscovite (up to 35\%) and, to a lesser degree, by ferrihydrite and Fe-OM associations (8-22\% and $15-30 \%$, respectively). The LCF results for the fine fraction $(<50 \mu \mathrm{m})$ show the same Fe speciation as in the bulk fraction, dominated by muscovite and goethite (20-35\% and 33-47\%, respectively). The sample from the redoxic horizon, $\mathrm{P} 4 \mathrm{C}$, presents a higher Fe proportion of ferrihydrite (22\%) than the other subsurface samples.

\subsubsection{In the $<4 \mu \mathrm{m}$ size fraction}

The size of the Fe oxyhydroxides identified by SEM is smaller than $4 \mu \mathrm{m}$ (Figure 5). Therefore, Fe speciation is also demonstrated in the $<4 \mu \mathrm{m}$ size fraction. The LCF results show that Fe is hosted by goethite, lepidocrocite, ferrihydrite, OM and muscovite (Figure 6). The strong difference with the bulk and fine fractions is the emergence of lepidocrocite (10-34\%). In order to validate the presence of lepidocrocite, the $\chi^{2}$ reduced factor was calculated as between the LCF performed with and without the lepidocrocite XANES spectrum. An improvement in the reduced $\chi^{2}$ value, ranging from 17 to $48 \%$, 
was calculated (for the six samples) when lepidocrocite was added as a reference compound. This improvement demonstrates that part of Fe is effectively hosted by lepidocrocite in the $<4 \mu \mathrm{m}$ fraction. The riverbank surface samples are characterized by a high proportion of goethite and ferrihydrite ( $46 \%$ and $31 \%$, respectively) and $\mathrm{P} 2 \mathrm{~B}$ (the most representative sample for the Fe deposit at the riverbank surface) (Figure 1) has the lowest proportion of lepidocrocite. The contribution of lepidocrocite is therefore higher in the albic horizon $(\mathrm{P} 4 \mathrm{~B} 1,34 \%)$ than at the riverbank surface.

\section{Discussion}

\subsection{Solid-phase Fe speciation along the riverbank}

In the riverbank, $\mathrm{Fe}$ speciation is made up of $\mathrm{Fe}$ oxyhydroxides (ferrihydrite, goethite and lepidocrocite), Fe-OM associations and phyllosilicates (mainly mica type). As expressed in Figure 6, at the surface, the Fe distribution is dominated by small poorly crystalline Fe phases (i.e. ferrihydrite and $\mathrm{Fe}-\mathrm{OM}$ associations) and goethite. At the subsurface, the Fe distribution is dominated by goethite and Fe-mica, the proportion of which increases at the expense of ferrihydrite and the $\mathrm{Fe}-\mathrm{OM}$ associations.

Goethite is an end-member of many Fe transformation routes. In aerated environments, the production of goethite takes a longer time than the production of ferrihydrite (Cornell and Schwertmann, 2003; Guo and Barnard, 2013). Therefore, at the riverbank surface, ferrihydrite is the first $\mathrm{Fe}(\mathrm{III})$ oxyhydroxide to be produced in response to the rapid $\mathrm{Fe}(\mathrm{II})$ oxidative precipitation induced by the presence of $\mathrm{O}_{2}$. The abundance of ferrihydrite (up to $31 \%$ ) on the riverbank surface is therefore induced by the faster kinetic formation of ferrihydrite. However, when Fe(II) flux is over, the fast ferrihydrite formation is therefore stopped and the ratio ferrihydrite/goethite can thus increase in favor of goethite. The erosion process of the riverbank via high water flow is thus a limiting factor for the transformation of ferrihydrite into goethite. By contrast, goethite is dominant in relation to ferrihydrite in the subsurface because it is possible that ferrihydrite transform into goethite over time (e.g. Cornell and Schwertmann, 2003). 
The ferrihydrite to goethite transformation may also be slowed down by surface coating with OM (Schwertmann, 1966; Jones et al., 2009) and the high amount of OM (OC content up to 3.9 wt\%) may favor the formation of Fe-OM associations (Kaiser and Guggenberger, 2003). Moreover, the precipitation of $\mathrm{Fe}$ in the presence of $\mathrm{OM}$ constrains the particle size and structural order of $\mathrm{Fe}$ (Schwertmann et al., 2005; Eusterhues et al., 2008; Cismasu et al., 2011; Pédrot et al., 2011). These results in wider lattice spacing, fewer crystal planes and Fe monomers, polymers and nanoparticles bound to OM (Vilgé-Ritter et al., 1999; Guénet et al., 2017). Threlfall (2003) showed that clusters and nanoparticles grow through a continuous supply of Fe(III) and Waychunas et al., (2005) demonstrated that this occurs through particle and cluster aggregation as observed in Figure 5. In ambient terrestrial environments (humid air, water and soil), wet surfaces favor solid transformations. The surface enthalpy is low for hydrous phases (oxyhydroxides) encouraging large surface area phases and allowing small particles to be thermodynamically more competitive than large ones (Navrotsky et al., 2008). Thus, over large surface areas (200-350 $\left.\mathrm{m}^{2} \mathrm{~g}^{-1}\right)$, ferrihydrite is thermodynamically competitive with goethite and lepidocrocite (Navrotsky et al., 2008).

Lepidocrocite is common in environments subject to oxic and anoxic fluctuations such as riparian wetlands (Schwertmann and Taylor, 1979; Thompson et al., 2006; Guénet et al., 2016). Guénet et al. (2016) demonstrated the presence of nano-lepidocrocite in the soil of the wetland studied here. By contrast, in the riverbank, only a small amount of lepidocrocite was detected in both the $<2 \mathrm{~mm}$ and $<$ $50 \mu \mathrm{m}$ fractions. Yamaguchi et al. (2014) demonstrated that a permanent supply of $\mathrm{O}_{2}$ at the surface and in the root channel induces a faster oxidation, favoring goethite and ferrihydrite, whereas lepidocrocite is the result of a slow oxidation. Here, in the riverbank, there is a permanent supply of $\mathrm{O}_{2}$ regardless of the water level, which favors the formation of ferrihydrite at the expense of lepidocrocite. Additionally, phosphates may also influence lepidocrocite formation (Cumplido et al., 2000). Goethite instead of lepidocrocite is formed at $\mathrm{P} / \mathrm{Fe}<0.5$ in the $\mathrm{pH}$ range 5-8.5. The results clearly show that $\mathrm{Fe}$ is dominant over $\mathrm{P}$ in our samples $(0.005<\mathrm{P} / \mathrm{Fe}<0.025$, Table EA-1). Finally, lepidocrocite may be a by-product of green rust oxidation (Schwertmann and Fechter, 1994). Although no green rust was identified in this study, Bourrié et al. (1999) observed green rusts in the deepest horizon of the wetland 
soil. However, in the $<4 \mu \mathrm{m}$ size fraction of the albic horizon, the LCF results indicate the presence of lepidocrocite, which may be trapped by phyllosilicates as previously observed by Peacock (1942) and Tarzi and Protz (1978). The XANES analysis performed on the $<4 \mu \mathrm{m}$ fraction can therefore be used to identify lepidocrocite in response to the strong phyllosilicate contribution.

Lastly, sample $\mathrm{P} 4 \mathrm{C}$, corresponding to the redoxic horizon, presents a high proportion of ferrihydrite whereas the other samples are enriched in goethite and mica. The redoxic horizon is in contact with the nitrate-enriched groundwater (Dia et al., 2000; Molénat et al., 2002) preventing the reduction of $\mathrm{Fe}(\mathrm{III})$ and favoring the fast accumulation of ferrihydrite.

At the riverbank surface, the main Fe hosting phases are therefore ferrihydrite and $\mathrm{Fe}-\mathrm{OM}$ associations in response to (i) the fast $\mathrm{Fe}$ (II) oxidation and (ii) the presence of $\mathrm{OM}$ favoring the formation of nanophases and preventing mineralogical transformation. Goethite develops in response to the transformation of the Fe precursor but its formation is limited by the erosion of the riverbank. In this system, speciation strongly varies at a small scale, demonstrating that the riverbank is a strategic area for the Fe biogeochemical cycle.

\subsection{Metal-bearing phases}

The variation in Fe speciation with the horizontal redox stratification may affect the metal cycle. The results of the PCA therefore demonstrate a correlation between Fe and trace metals (Figure 3). Due to the large specific surface area $\left(200-600 \mathrm{~m}^{2} \mathrm{~g}^{-1}\right)$, the high density of their hydroxyl surface groups and their nano-size, ferrihydrite and Fe clusters bound to OM are efficient metal sorbents and vectors for trace metals (Dzombak and Morel, 1990; Hassellöv and von der Krammer, 2008). Moreover, freshly precipitated $\mathrm{Fe}$ oxyhydroxides have an adsorption capacity ten times that of aged oxides that has been found to correspond to a tenfold difference in cation exchange capacity and surface area (Shuman, 1977).

Depending on the $\mathrm{pH}$, metals associated with small ferrihydrite aggregates can be mobilized in response to the fast ferrihydrite dissolution under reducing conditions. When metals are associated with $\mathrm{Fe}$ clusters bound to $\mathrm{OM}$, their mobility is mainly controlled by the mobility of the $\mathrm{OM}$ 
aggregates. In this hypothesis, goethite is not considered as a major Fe reactive phase. Given that it only occurs in a small amount, lepidocrocite also weakly influences the behavior of the metals. To determine the reactive Fe phases able to affect the behavior of metals, the "reactive Fe" content is calculated summing $\mathrm{Fe}$ as ferrihydrite and Fe clusters bound to OM. Elemental contents (As, $\mathrm{Co}, \mathrm{Cu}$, $\mathrm{Ni}, \mathrm{Pb}$ and $\mathrm{Zn}$ ) are plotted against the "reactive $\mathrm{Fe}$ " and $\mathrm{OC}$ contents (Figure 7) and a variable "reactive Fe" was added in the Pearson correlation matrix to provide Pearson factor (PF) and p values. Arsenic, $\mathrm{Co}, \mathrm{Cu}$ and $\mathrm{Ni}$ were selected due to their strong Pearson correlation factor with $\mathrm{Fe}$ (Figure 3, Table EA-2) and their significant accumulation in the $<2 \mathrm{~mm}$ and $<50 \mu \mathrm{m}$ fractions at the riverbank surface (Figure 2). By contrast, $\mathrm{Pb}$ and $\mathrm{Zn}$ were selected because of their strong Pearson correlation factor with the OC and $\mathrm{S}_{\text {tot }}$ contents (Figure 3, Table EA-2) and their slight accumulation at the riverbank surface.

Numerous studies have demonstrated that, in wetlands, As mobility is mainly controlled by the behavior of Fe(III) oxyhydroxides in response to redox variations (e.g. Kocar et al., 2008; Polizzotto et al., 2008; Davranche et al., 2013). Iron may also act as bridge between As and OM as ions or nanoparticles (Ritter et al., 2006; Mikutta and Kretzschmar, 2011, Catrouillet et al., 2014; Guénet et al., 2016). In the riverbank, the As content increases with the increasing "reactive Fe" content (Figure $\left.7 \mathrm{a}, \mathrm{R}^{2}=0.97\right)$. Conversely, samples enriched in OC do not affect the correlation between As and "reactive Fe" (Figure 7a). In the riverbank, the behavior of As is therefore strongly controlled by the "reactive Fe" phases, i.e. ferrihydrite and Fe clusters bound to $\mathrm{OM}(\mathrm{PF}=0.97, \mathrm{p}$ value $<0.01$, Table EA-2).

Grybos et al. (2007) identified various trace metal behaviors in the organo-mineral soil horizon of the Mercy wetland. They showed that $\mathrm{Co}$ was mainly bound to Fe-oxyhydroxides while $\mathrm{Pb}$ and $\mathrm{Ni}$ were bound to both $\mathrm{OM}$ and Fe-oxyhydroxides. At the riverbank, Co exhibits a correlation with "reactive $\mathrm{Fe} "(\mathrm{PF}=0.71, \mathrm{p}$ value $<0.01$, Table EA-2). However, depending on the size fraction, two distinct trends are observed (Figure 7b). The linear regression between $\mathrm{Co}$ and "reactive $\mathrm{Fe}$ " is higher for the $<$ $2 \mathrm{~mm}$ fraction $\left(\mathrm{R}^{2}=0.70\right)$ than for the $<50 \mu \mathrm{m}$ fraction $\left(\mathrm{R}^{2}=0.52\right)$. In the $<2 \mathrm{~mm}$ fraction, the amounts of OC and Fe are higher than in the $<50 \mu \mathrm{m}$ fraction (Table EA-1) and Co has a higher 
correlation with them in the $<2 \mathrm{~mm}$ fraction (Figure $7 \mathrm{~b}$ ). Thus, the distribution of Co evolves in relation with the amounts of $\mathrm{Fe}$ oxyhydroxide and OM. Moreover, a high Mn content is measured in the ferric deposit crust $\left(\mathrm{P} 3,[\mathrm{Mn}]=2.56 \mathrm{~g} \mathrm{~kg}^{-1}\right)$ and Mn oxides are well-known to have strong affinity for Co (e.g. Burns, 1976; Crowther et al., 1983).

It is difficult to precisely quantify the affinity of copper with Fe oxyhydroxides and OM due to the precipitation or re-adsorption of the reduced phase (Grybos et al., 2007). However, at the riverbank surface, $\mathrm{Cu}$ seems to be clearly bound to "reactive $\mathrm{Fe}$ " content $\left(\mathrm{R}^{2}=0.79, \mathrm{PF}=0.77, \mathrm{p}\right.$ value $\left.<0.01\right)$; the outlier ( $\mathrm{P} 15-10, \mathrm{OC}=3.4 \mathrm{wt} \%)$ is a reminder that $\mathrm{Cu}$ has also a strong affinity for $\mathrm{OM}$ (Figure $7 \mathrm{c})$.

Nickel and $\mathrm{Pb}$ are mainly controlled by $\mathrm{OM}$ and Fe oxyhydroxides in the wetland soil (Grybos et al., 2007). In the riverbank, the same relation is observed between Ni, "reactive Fe" and OC (Figure 7d). By contrast, the amount of $\mathrm{Pb}$ increases with the increasing $\mathrm{OC}$ content and the decreasing $\mathrm{Fe}-\mathrm{Fh} / \mathrm{Fe}$ $\mathrm{OM}$ ratio (Figure 7e). At the riverbank surface, the $\mathrm{Pb}$ content varies from 17 to $22 \mathrm{mg} \mathrm{kg}^{-1}$ for the organic-poor samples ( $\mathrm{OC}=1.5$ to $2.4 \mathrm{wt} \%$ ), and from 20 to $40 \mathrm{mg} \mathrm{kg}^{-1}$ for the organic-rich samples $(\mathrm{OC}=1.9$ to $3.9 \mathrm{wt} \%)$ (Table EA-1). As demonstrated by the PCA, the Pb distribution has a higher correlation with OC $(0.75, \mathrm{p}$ value $<0.01$, Table EA-2) or potentially Fe bound to OM than with "reactive Fe" ( $\mathrm{PF}=0.37)$. Last, $\mathrm{Zn}$ is slightly enriched at the riverbank surface but no correlation was clearly allow distinguishing a stronger association with "reactive $\mathrm{Fe}$ " $(\mathrm{PF}=0.56, \mathrm{p}$ value $<0.05)$ than $\mathrm{OC}(\mathrm{PF}=0.64, \mathrm{p}$ value $<0.01)($ Figure $7 \mathrm{f}$, Table EA-2)

By contrast, the albic horizon (P4B1 and P4B2) exhibits a low metal content, especially in As (8-9 mg $\left.\mathrm{kg}^{-1}\right)$ and Co $\left(6 \mathrm{mg} \mathrm{kg}^{-1}\right)$ (Table EA-1), which are strongly correlated with Fe oxyhydroxides at the riverbank surface. Iron speciation in the albic horizon is dominated by goethite and Fe-mica. Copper, $\mathrm{Ni}, \mathrm{Pb}$ and $\mathrm{Zn}$ can be potentially adsorbed onto clay minerals (e.g. Bhattacharyya and Gupta, 2008; Uddin, 2017). Moreover, a recent study has provided chemical models showing that, for $\mathrm{pH}$ values ranging from 6 to 7 , the sorption onto goethite is $100 \%$ for $\mathrm{Cu}$ and $\mathrm{Pb}\left(5.10^{-3} \mathrm{~mol} \mathrm{~kg}^{-1}\right.$ goethite) and almost $80 \%$ for $\mathrm{Zn}\left(4.10^{-3} \mathrm{~mol} \mathrm{~kg}^{-1}\right.$ goethite $)$ (Komárek et al., 2018). The $\mathrm{pH}$ of the wetland soil solution varies 
from 6.0 to 7.1 (Olivié-Lauquet et al., 2001; Pourret et al., 2007). As a result, $\mathrm{Cu}, \mathrm{Ni}, \mathrm{Pb}$ and $\mathrm{Zn}$ are probably adsorbed to goethite in the albic horizon.

This study shows that the soil in the riverbank is enriched in the Fe-phases which modifies the behavior of the trace metals in interaction with Fe oxyhydroxides with the following sequence As > $\mathrm{Cu}>\mathrm{Co}, \mathrm{Ni}>\mathrm{Pb}>\mathrm{Zn}$. Three main groups can be identified: As (metalloid), $\mathrm{Cu}, \mathrm{Co}, \mathrm{Ni}$ (metal transition) and $\mathrm{Pb}, \mathrm{Zn}$ (post metal transition). Consequently, the trace metal chemical properties controlled their scavenging at the riverbank surface.

\subsection{Riverbanks in wetlands}

In the riverbank, small and mainly poorly crystalline Fe oxyhydroxides are formed in response to the flow of $\mathrm{Fe}(\mathrm{II})$ dissolved in water, $\mathrm{O}_{2}$ routes in the soil porosity and a high amount of $\mathrm{OM}$ which prevent the growth and crystallization of Fe oxyhydroxides. These ferric deposits are correlated with high trace metal contents $(\mathrm{As}>\mathrm{Cu}>\mathrm{Co}, \mathrm{Ni}>\mathrm{Pb}>\mathrm{Zn}$ ) suggesting that they act as a "geochemical filter" by trapping chemical elements. During periods of high water levels, the erosion of the riverbank depending on the river flow removes the ferric deposits and the associated elements (Figure 8).

$\mathrm{Fe}(\mathrm{III})$ oxyhydroxides release Fe(II,III) into the solution through reductive dissolution, hydrolyze and complexation (Schwertmann, 1991). The solubility of Fe(III) oxyhydroxides in water is very low (Schwertmann, 1991) and their solubility product range from 0 to 3.5 (log Ksp) with the highest value for ferrihydrite (Lindsay, 1988). The solubility also depends on the Fe oxyhydroxides properties (such as their structure, crystallinity, particle size) (Larsen and Postma, 2001, Kraemer, 2004).

In the physicochemical conditions of the river, the solubility is strongly controlled by the $\mathrm{pH}$. The river water $\mathrm{pH}$ (outlet) of the Mercy watershed varies from 6.6 to 7.6 between December and May (Olivié-Lauquet et al., 2001) and therefore does not favor the solubilization of Fe oxyhydroxides in the river. The $\mathrm{pH}$ of the river water is higher than the $\mathrm{pH}$ of the soil solution (from 6.0 to 7.1), thereby inhibiting the solubilization of the ferrihydrite and Fe clusters bound to OM (Avena and Koopal, 1998; Kaiser and Zech, 1999) and the subsequent release of associated metals. 
Moreover, the river is always maintained in oxic conditions thereby preventing the reduction of $\mathrm{Fe}(\mathrm{III})$ in the hyporheic zone. These erosion products enrich the river water in Fe oxyhydroxides in the form of suspended material (particles and colloids) (Figure 8). However, when the flow velocity of the water is low, the ferric deposits precipitate due to the reduced Fe(II) fluxes onto the riverbank surface. Low water flow is therefore a key factor for the formation of ferric deposits as well as the accumulation of metals at the surface and prevents the erosion of the riverbank surface (Figure 8).

\section{Conclusions}

This study shows that $\mathrm{Fe}$ speciation at the riverbank interface between the wetland and the river is a key factor of metal fluxes in rivers. In the case of the Mercy wetland in the Kervidy-Naizin subcatchment, ferric deposits observed at the riverbank surface are mainly dominated by the formation of ferrihydrite and Fe clusters bound to OM. In the subsurface, Fe is mainly present as goethite and mica. This Fe speciation is the result of the fast oxidation reaction occurring in response to the input of $\mathrm{O}_{2}$ in the riverbank porosity. Consequently, the small structure and poorly crystalline form of these ferric deposits make them strong scavengers of metallic trace elements. The results demonstrate that the combination of small and poorly crystalline $\mathrm{Fe}$ oxyhydroxides and $\mathrm{OM}$ are responsible for an accumulation of metals (As, $\mathrm{Co}, \mathrm{Cu}, \mathrm{Ni}, \mathrm{Pb}, \mathrm{Zn}$, etc.). However, distinct metal behaviors are observed relative to the Fe oxyhydroxides and $\mathrm{OM}$. At the riverbank surface, Fe oxyhydroxides accumulate As, organic matter is the major scavenger of $\mathrm{Pb}$ whereas the distribution of $\mathrm{Co}, \mathrm{Cu}$ and $\mathrm{Ni}$ is primarily controlled by $\mathrm{OM}$ and Fe oxyhydroxides.

Metal transport is thus dependent on its main bearing phases, poorly crystalline Fe-oxide (potentially soluble), Fe clusters bound to $\mathrm{OM}$ and $\mathrm{OM}$ (not as soluble). This dissolution process is essential to understanding the behavior of metals in aquatic systems (transport, bioavailability, etc.). In wetlands, the alternation of low and high water levels is responsible for the formation and remobilization of these ferric deposits, enriched in $\mathrm{OM}$ and trace metals, in the river. When the water level is low and without river flow, the ferric deposits remain at the riverbank surface. Their formation occurs when the water flow is low in the river, when the riverbank is charged with water, thereby favoring a reduced 
$\mathrm{Fe}$ (II) fluxes in anoxic conditions. At the riverbank surface, Fe oxyhydroxides precipitation forms due to the presence of $\mathrm{O}_{2}$. Metal accumulation occurs during these conditions. Then, when the water level is high (high flow), strong erosion removes these deposits in the river. The physical and chemical parameters of the river ( $\mathrm{pH}$ ranging from 6.6 to 7.6 and continuous oxic conditions) do not allow the dissolution of Fe oxyhydroxides and OM. Therefore, the ferric deposits and associated trace metals are maintained as colloids/particles and are exported to the outlet. All of the results presented in this current work demonstrate that ferric deposits trap metals on a seasonal basis and are therefore a key factor in the mobilization of metals during riverbank erosion by river flow. Controlled experiments should be conducted to simulate riverbank environment in a closed system under different frequency and duration of wet and dry cycles in order to identify the processes (sorption/desorption, precipitation/dissolution and complexation/decomplexation) controlling metal mobility in riverbank.

\section{Acknowledgments}

We would like to thank SOLEIL synchrotron for providing the synchrotron radiation facilities and specifically the LUCIA beamline staff for their support. The authors would also like to thank Francis Gouttefangeas (CMEBA, France) for his insights and for providing access to the SEM facilities, Renaud Gley for his assistance with the XRD analysis on the clay fraction, as well as Martine Bouhnik-Le Coz for her assistance with the chemical analysis and sample preparation. Dr. S. Mullin is acknowledged for post-editing the English style (http://www.proz.com/profile/677614).

\section{References}

Avena, M. J., \& Koopal, L. K. (1998). Desorption of humic acids from an iron oxide surface. Environmental Science \& Technology, 32(17), 2572-2577.

Benedetti, M. F., Van Riemsdijk, W. H., Koopal, L. K., Kinniburgh, D. G., Gooddy, D. C., \& Milne, C. J. (1996). Metal ion binding by natural organic matter: from the model to the field. Geochimica et Cosmochimica Acta, 60(14), 2503-2513.

Bhattacharyya, K. G., \& Gupta, S. S. (2008). Adsorption of a few heavy metals on natural and modified kaolinite and montmorillonite: A review. Advances in Colloid and Interface Science, 140(2), 114-131. http://doi.org/10.1016/j.cis.2007.12.008 
Borch, T., Kretzschmar, R., Kappler, A., Cappellen, P. V., Ginder-Vogel, M., Voegelin, A., \& Campbell, K. (2009). Biogeochemical redox processes and their impact on contaminant dynamics. Environmental Science \& Technology, 44(1), 15-23.

Bourrié, G., Trolard, F., Jaffrezic, J.-M. R. G., Maître, V., \& Abdelmoula, M. (1999). Iron control by equilibria between hydroxy-Green Rusts and solutions in hydromorphic soils. Geochimica et Cosmochimica Acta, 63(19), 3417-3427.

Buffle, J. (1988). Complexation reactions in aquatic systems. An analytical approach.

Carignan, J., Hild, P., Mevelle, G., Morel, J., \& Yeghicheyan, D. (2001). Routine analyses of trace elements in geological samples using flow injection and low pressure on-line liquid chromatography coupled to ICP-MS: A study of geochemical reference materials BR, DR-N, UB-N, AN-G and GH. Geostandards Newsletter, 25(2-3), 187-198.

Catrouillet, C., Davranche, M., Dia, A., Bouhnik-Le Coz, M., Marsac, R., Pourret, O., \& Gruau, G. (2014). Geochemical modeling of Fe (II) binding to humic and fulvic acids. Chemical Geology, 372, $109-118$.

Charlatchka, R., \& Cambier, P. (2000). Influence of reducing conditions on solubility of trace metals in contaminated soils. Water, Air, and Soil Pollution, 118(1), 143-168. http://doi.org/10.1023/A:1005195920876

Chen, C., Kukkadapu, R. K., Lazareva, O., \& Sparks, D. L. (2017). Solid-Phase Fe Speciation along the Vertical Redox Gradients in Floodplains using XAS and Mössbauer Spectroscopies. Environmental Science \& Technology, 51(14), 7903-7912. http://doi.org/10.1021/acs.est.7b00700

Chuan, M. C., Shu, G. Y., \& Liu, J. C. (1996). Solubility of heavy metals in a contaminated soil: Effects of redox potential and pH. Water, Air, and Soil Pollution, 90(3), 543-556. http://doi.org/10.1007/BF00282668

Cismasu, A. C., Michel, F. M., Tcaciuc, A. P., Tyliszczak, T., \& Brown Jr, G. E. (2011). Composition and structural aspects of naturally occurring ferrihydrite. Comptes Rendus Geoscience, 343(2-3), 210 218.

Cornell, R. M., Mann, S., \& Skarnulis, A. J. (1983). A high-resolution electron microscopy examination of domain boundaries in crystals of synthetic goethite. Journal of the Chemical Society, Faraday Transactions 1: Physical Chemistry in Condensed Phases, 79(11), 2679-2684.

Cornell, R. M., \& Schwertmann, U. (2003). The Iron Oxides: Structure, Properties, Reactions, Occurrence and Uses.

Cumplido, J., Barrón, V., \& Torrent, J. (2000). Effect of phosphate on the formation of nanophase lepidocrocite from Fe (II) sulfate. Clays and Clay Minerals, 48(5), 503-510.

Datta, S., Mailloux, B., Jung, H.-B., Hoque, M. A., Stute, M., Ahmed, K. M., \& Zheng, Y. (2009). Redox trapping of arsenic during groundwater discharge in sediments from the Meghna riverbank in Bangladesh. Proceedings of the National Academy of Sciences, 106(40), 16930-16935.

Davranche, M., Bollinger, J.-C., \& Bril, H. (2003). Effect of reductive conditions on metal mobility from wasteland solids: an example from the Mortagne-du-Nord site (France). Applied Geochemistry, 18(3), 383-394. http://doi.org/10.1016/S0883-2927(02)00075-6

Davranche, M., Dia, A., Fakih, M., Nowack, B., Gruau, G., Ona-nguema, G., Petitjean, P., Martin, S., \& Hochreutener, R. (2013). Organic matter control on the reactivity of Fe (III)-oxyhydroxides and associated As in wetland soils: a kinetic modeling study. Chemical Geology, 335, 24-35. 
Dia, A., Gruau, G., Olivié-Lauquet, G., Riou, C., Molénat, J., \& Curmi, P. (2000). The distribution of rare earth elements in groundwaters: assessing the role of source-rock composition, redox changes and colloidal particles. Geochimica et Cosmochimica Acta, 64(24), 4131-4151.

Du Laing, G., Vanthuyne, D. R. J., Vandecasteele, B., Tack, F. M. G., \& Verloo, M. G. (2007). Influence of hydrological regime on pore water metal concentrations in a contaminated sedimentderived soil. Air Pollution and Climate Change: A Global Overview of the Effects on Forest Vegetation, 147(3), 615-625. http://doi.org/10.1016/j.envpol.2006.10.004

Du Laing, G., Rinklebe, J., Vandecasteele, B., Meers, E., \& Tack, F. M. (2009). Trace metal behaviour in estuarine and riverine floodplain soils and sediments: a review. Science of the Total Environment, 407(13), 3972-3985.

Dzombak, D. A., \& Morel, F. M. M. (1990). Surface complexation modeling: hydrous ferric oxide. John Wiley \& Sons.

Eusterhues, K., Wagner, F. E., Häusler, W., Hanzlik, M., Knicker, H., Totsche, K. U., Kögel-Knabner, I., \& Schwertmann, U. (2008). Characterization of ferrihydrite-soil organic matter coprecipitates by Xray diffraction and Mossbauer spectroscopy. Environmental Science \& Technology, 42(21), 78917897.

Flank, A.-M., Cauchon, G., Lagarde, P., Bac, S., Janousch, M., Wetter, R., Dubuisson, J.-M., Idir, M., Langlois, F., \& Moreno, T. (2006). LUCIA, a microfocus soft XAS beamline. Nuclear Instruments and Methods in Physics Research Section B: Beam Interactions with Materials and Atoms, 246(1), 269-274.

Fordham, A. W. (1970). Sorption and precipitation of iron on kaolinite. III. The solubility of iron (III) hydroxides precipated in the presence of kaolinite. Soil Research, 8(1), 107-122.

Francis, A. J., \& Dodge, C. J. (1990). Anaerobic microbial remobilization of toxic metals coprecipitated with iron oxide. Environmental Science \& Technology, 24(3), 373-378.

Gault, A. G., Langley, S., Ibrahim, A., Renaud, R., Takahashi, Y., Boothman, C., Lloyd, J.R., Clark, I.D., Ferris, F.G., \& Fortin, D. (2012). Seasonal Changes In Mineralogy, Geochemistry and Microbial Community of Bacteriogenic Iron Oxides (BIOS) Deposited in a Circumneutral Wetland. Geomicrobiology Journal, 29(2), 161-172. http://doi.org/10.1080/01490451.2010.532196

Grybos, M., Davranche, M., Gruau, G., \& Petitjean, P. (2007). Is trace metal release in wetland soils controlled by organic matter mobility or Fe-oxyhydroxides reduction? Journal of Colloid and Interface Science, 314(2), 490-501.

Guénet, H., Davranche, M., Vantelon, D., Pédrot, M., Al-Sid-Cheikh, M., Dia, A., \& Jestin, J. (2016). Evidence of organic matter control on As oxidation by iron oxides in riparian wetlands. Chemical Geology, 439, 161-172. http://doi.org/10.1016/j.chemgeo.2016.06.023

Guénet, H., Davranche, M., Vantelon, D., Gigault, J., Prévost, S., Taché, O., Jaksch, S., Pédrot, M., Dorcet, V., \& Boutier, A. (2017). Characterization of iron-organic matter nano-aggregate networks through a combination of SAXS/SANS and XAS analyses: impact on As binding. Environmental Science: Nano, 4(4), 938-954.

Guo, H., \& Barnard, A. S. (2013). Naturally occurring iron oxide nanoparticles: morphology, surface chemistry and environmental stability. Journal of Materials Chemistry A, 1(1), 27-42.

Hassellov, M., \& von der Kammer, F. (2008). Iron oxides as geochemical nanovectors for metal transport in soil-river systems. Elements, 4(6), 401-406. 
Jones, A. M., Collins, R. N., Rose, J., \& Waite, T. D. (2009). The effect of silica and natural organic matter on the $\mathrm{Fe}$ (II)-catalysed transformation and reactivity of Fe (III) minerals. Geochimica et Cosmochimica Acta, 73(15), 4409-4422.

Kaiser, K., \& Zech, W. (1999). Release of natural organic matter sorbed to oxides and a subsoil. Soil Science Society of America Journal, 63(5), 1157-1166.

Kaiser, K., \& Guggenberger, G. (2003). Mineral surfaces and soil organic matter. European Journal of Soil Science, 54(2), 219-236.

Kerr, S. C., Shafer, M. M., Overdier, J., \& Armstrong, D. E. (2008). Hydrologic and biogeochemical controls on trace element export from northern Wisconsin wetlands. Biogeochemistry, 89(3), 273-294.

Kocar, B. D., Polizzotto, M. L., Benner, S. G., Ying, S. C., Ung, M., Ouch, K., Samreth, S., Suy, B., Phan, K., \& Sampson, M. (2008). Integrated biogeochemical and hydrologic processes driving arsenic release from shallow sediments to groundwaters of the Mekong delta. Applied Geochemistry, 23(11), 3059-3071.

Komárek, M., Antelo, J., Králová, M., Veselská, V., Č́́halová, S., Chrastný, V., Ettler, V., Filip, J., $\mathrm{Yu}, \mathrm{Q}$, Fein, J. B. \& Koretsky, C.M. (2018). Revisiting models of $\mathrm{Cd}, \mathrm{Cu}, \mathrm{Pb}$ and $\mathrm{Zn}$ adsorption onto $\mathrm{Fe}$ (III) oxides. Chemical Geology.

Kraemer, S. M. (2004). Iron oxide dissolution and solubility in the presence of siderophores. Aquatic Sciences, 66(1), 3-18.

Lambert, T., Pierson-Wickmann, A. C., Gruau, G., Jaffrezic, A., Petitjean, P., Thibault, J. N., \& Jeanneau, L. (2013). Hydrologically driven seasonal changes in the sources and production mechanisms of dissolved organic carbon in a small lowland catchment. Water Resources Research, 49(9), 5792-5803.

Larsen, O., \& Postma, D. (2001). Kinetics of reductive bulk dissolution of lepidocrocite, ferrihydrite, and goethite. Geochimica et Cosmochimica Acta, 65(9), 1367-1379.

Lee, G., Bigham, J. M., \& Faure, G. (2002). Removal of trace metals by coprecipitation with Fe, Al and Mn from natural waters contaminated with acid mine drainage in the Ducktown Mining District, Tennessee. Applied Geochemistry, 17(5), 569-581.

Lindsay, W. L. (1988). Solubility and redox equilibria of iron compounds in soils. In Iron in Soils and Clay Minerals (pp. 37-62). Springer.

Lynch, S. F. L., Batty, L. C., \& Byrne, P. (2014). Environmental risk of metal mining contaminated river bank sediment at redox-transitional zones. Minerals, 4(1), 52-73.

Lynch, S. F. L., Batty, L. C., \& Byrne, P. (2017). Critical control of flooding and draining sequences on the environmental risk of Zn-contaminated riverbank sediments. Journal of Soils and Sediments, 17(11), 2691-2707. http://doi.org/10.1007/s11368-016-1646-4

McKenzie, R. M. (1980). The adsorption of lead and other heavy metals on oxides of manganese and iron. Soil Research, 18(1), 61-73.

Mikutta, C., \& Kretzschmar, R. (2011). Spectroscopic evidence for ternary complex formation between arsenate and ferric iron complexes of humic substances. Environmental Science \& Technology, 45(22), 9550-9557.

Molénat, J., Durand, P., Gascuel-Odoux, C., Davy, P., \& Gruau, G. (2002). Mechanisms of nitrate transfer from soil to stream in an agricultural watershed of French Brittany. Water, Air, and Soil Pollution, 133(1-4), 161-183. 
Mustafa, S., \& Haq, I. (1988). Adsorption of cud(II), cod(II), and Ni(II) on amorphous iron hydroxide from aqueous electrolyte solution. Environmental Technology Letters, 9(12), 1379-1386. http://doi.org/10.1080/09593338809384704

Navrotsky, A., Mazeina, L., \& Majzlan, J. (2008). Size-driven structural and thermodynamic complexity in iron oxides. Science, 319(5870), 1635-1638.

Olivie-Lauquet, G., Gruau, G., Dia, A., Riou, C., Jaffrezic, A., \& Henin, O. (2001). Release of trace elements in wetlands: role of seasonal variability. Water Research, 35(4), 943-952.

Peacock, M. (1942). On goethite and lepidocrocite. Trans. R. Soc. Can. Sect. 3, 36, 107-118.

Pédrot, M., Le Boudec, A., Davranche, M., Dia, A., \& Henin, O. (2011). How does organic matter constrain the nature, size and availability of Fe nanoparticles for biological reduction? Journal of Colloid and Interface Science, 359(1), 75-85.

Pellerin, J., \& Van Vliet-Lanoë, B. (1998). Le bassin du Coët-Dan au coeur du Massif armoricain. 2. Analyse cartographique de la région de Naizin. Cheverry, C., Éditeur, Agriculture Intensive et Qualité Des Eaux, 17-24.

Polizzotto, M. L., Kocar, B. D., Benner, S. G., Sampson, M., \& Fendorf, S. (2008). Near-surface wetland sediments as a source of arsenic release to ground water in Asia. Nature, 454(7203), 505.

Pourret, O., Dia, A., Davranche, M., Gruau, G., Hénin, O., \& Angee, M. (2007). Organo-colloidal control on major-and trace-element partitioning in shallow groundwaters: confronting ultrafiltration and modelling. Applied Geochemistry, 22(8), 1568-1582.

Ravel, B., \& Newville, M. (2005). ATHENA, ARTEMIS, HEPHAESTUS: data analysis for X-ray absorption spectroscopy using IFEFFIT. Journal of Synchrotron Radiation, 12(4), 537-541.

Ritter, K., Aiken, G., R., Ranville, J. F., Bauer, M., \& Macalady, D. L. (2006). Evidence for the aquatic binding of arsenate by natural organic matter- suspended Fe (III). Environmental Science \& Technology, 40(17), 5380-5387.

Roden, E. E. (2003). Fe (III) oxide reactivity toward biological versus chemical reduction. Environmental Science \& Technology, 37(7), 1319-1324.

Ross, G. J., Miles, N. M., \& Kodama, H. (1979). Occurrence and determination of lepidocrocite in Canadian soils. Canadian Journal of Soil Science, 59(2), 155-162.

Schulz-Zunkel, C., \& Krueger, F. (2009). Trace metal dynamics in floodplain soils of the River Elbe: a review. Journal of Environmental Quality, 38(4), 1349-1362.

Schwertmann, U. (1966). Inhibitory effect of soil organic matter on the crystallization of amorphous ferric hydroxide. Nature, 212(5062), 645.

Schwertmann, U., \& Taylor, R. M. (1979). Natural and synthetic poorly crystallized lepidocrocite. Clay Minerals, 14(4), 285-293.

Schwertmann, U. (1991). Solubility and dissolution of iron oxides. Plant and Soil, 130(1-2), 1-25.

Schwertmann, U., \& Fechter, A. (1994). Transformation to lepidocrocite. Clay Minerals, 29, 87-92.

Schwertmann, U., Wagner, F., \& Knicker, H. (2005). Ferrihydrite-humic associations. Soil Science Society of America Journal, 69(4), 1009-1015. 
Shaheen, S. M., \& Rinklebe, J. (2014). Geochemical fractions of chromium, copper, and zinc and their vertical distribution in floodplain soil profiles along the Central Elbe River, Germany. Geoderma, 228, $142-159$.

Shuman, L. M. (1977). Adsorption of Zn by Fe and Al Hydrous Oxides as Influenced by Aging and pH 1. Soil Science Society of America Journal, 41(4), 703-706.

Stahl, M. O., Harvey, C. F., van Geen, A., Sun, J., Thi Kim Trang, P., Mai Lan, V., Mai Phuong, T., Hung Viet, P., \& Bostick, B. C. (2016). River bank geomorphology controls groundwater arsenic concentrations in aquifers adjacent to the Red River, Hanoi Vietnam. Water Resources Research, 52(8), 6321-6334.

Tarzi, J. G., \& Protz, R. (1978). The occurrence of lepidocrocite in two well-drained Ontario soils. Clays and Clay Minerals, 26(6), 448-451.

Taylor, K. G., \& Konhauser, K. O. (2011). Iron in Earth surface systems: A major player in chemical and biological processes. Elements, 7(2), 83-88.

Thompson, A., Chadwick, O. A., Rancourt, D. G., \& Chorover, J. (2006). Iron-oxide crystallinity increases during soil redox oscillations. Geochimica et Cosmochimica Acta, 70(7), 1710-1727.

Threlfall, T. (2003). Structural and Thermodynamic Explanations of Ostwald's Rule. Organic Process Research \& Development, 7(6), 1017-1027. http://doi.org/10.1021/op0300261

Trivedi, P., \& Axe, L. (2001). Ni and Zn sorption to amorphous versus crystalline iron oxides: Macroscopic studies. Journal of Colloid and Interface Science, 244(2), 221-229.

Uddin, M. K. (2017). A review on the adsorption of heavy metals by clay minerals, with special focus on the past decade. Chemical Engineering Journal, 308, 438-462. http://doi.org/10.1016/j.cej.2016.09.029

Vantelon, D., Trcera, N., Roy, D., Moreno, T., Mailly, D., Guilet, S., Metchalkov, E., Delmotte, F., Lassalle, B., \& Lagarde, P. (2016). The LUCIA beamline at SOLEIL. Journal of Synchrotron Radiation, 23(2), 635-640.

Vilgé-Ritter, A., Rose, J., Masion, A., Bottero, J.-Y., \& Lainé, J.-M. (1999). Chemistry and structure of aggregates formed with Fe-salts and natural organic matter. Colloids and Surfaces A: Physicochemical and Engineering Aspects, 147(3), 297-308.

Vodyanitskii, Y. N. (2010). Iron hydroxides in soils: a review of publications. Eurasian Soil Science, 43(11), 1244-1254.

Waychunas, G. A., Kim, C. S., \& Banfield, J. F. (2005). Nanoparticulate iron oxide minerals in soils and sediments: unique properties and contaminant scavenging mechanisms. Journal of Nanoparticle Research, 7(4), 409-433.

Wilke, M., Farges, F., Petit, P.-E., Brown Jr, G. E., \& Martin, F. (2001). Oxidation state and coordination of Fe in minerals: An Fe K-XANES spectroscopic study. American Mineralogist, 86(56), 714-730.

Yamaguchi, N., Ohkura, T., Takahashi, Y., Maejima, Y., \& Arao, T. (2014). Arsenic distribution and speciation near rice roots influenced by iron plaques and redox conditions of the soil matrix. Environmental Science \& Technology, 48(3), 1549-1556.

Zachara, J. M., Fredrickson, J. K., Smith, S. C., \& Gassman, P. L. (2001). Solubilization of Fe (III) oxide-bound trace metals by a dissimilatory Fe (III) reducing bacterium. Geochimica et Cosmochimica Acta, 65(1), 75-93. 


\section{Highlights}

$\mathrm{Fe}(\mathrm{II})$ precipitates as solid $\mathrm{Fe}(\mathrm{III})$ at the riverbank surface

Ferrihydrite and Fe-OM associations are the main Fe-phases at the riverbank surface

Metals bound to $\mathrm{Fe}$ oxyhydroxides and OM accumulate at the riverbank surface

Fe oxyhydroxides at the riverbank act as seasonal scavenger of metals

Riverbank erosion is the key factor of metals mobilization as colloids in the river 


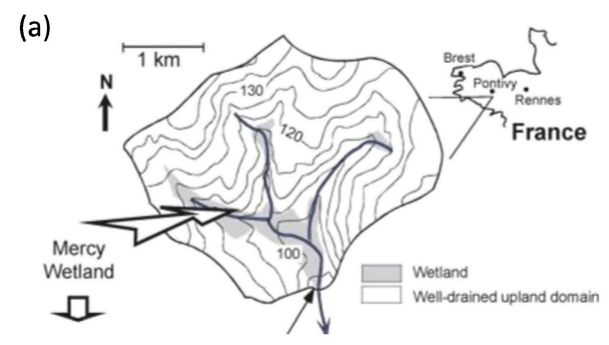

(c)
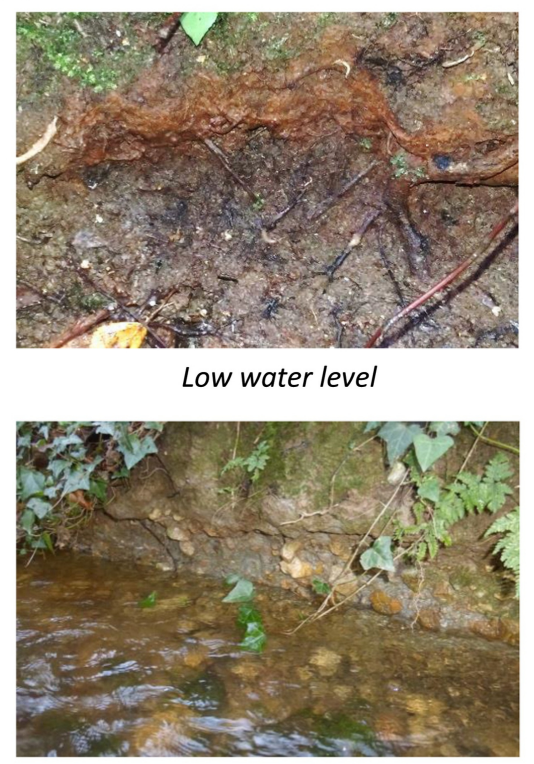

High water level (b)
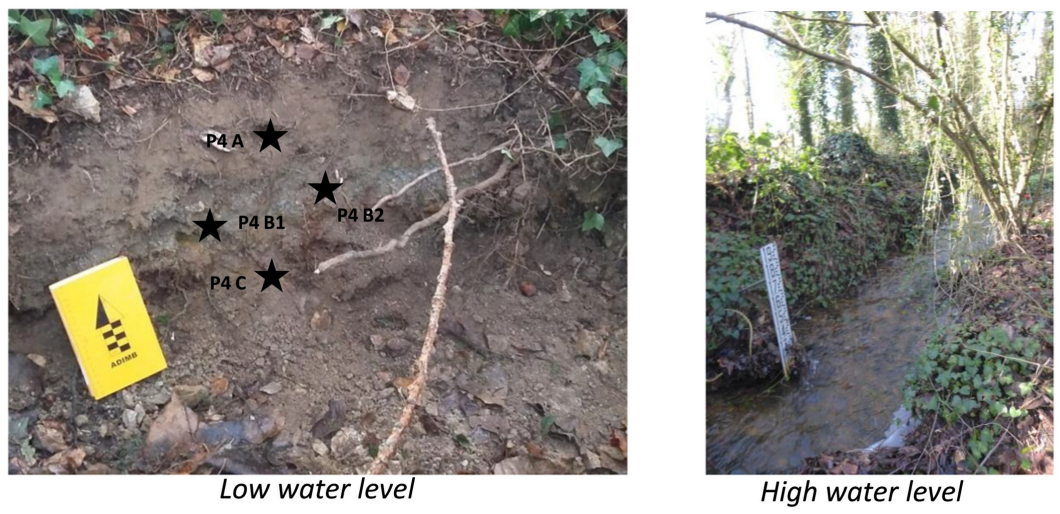

(d)

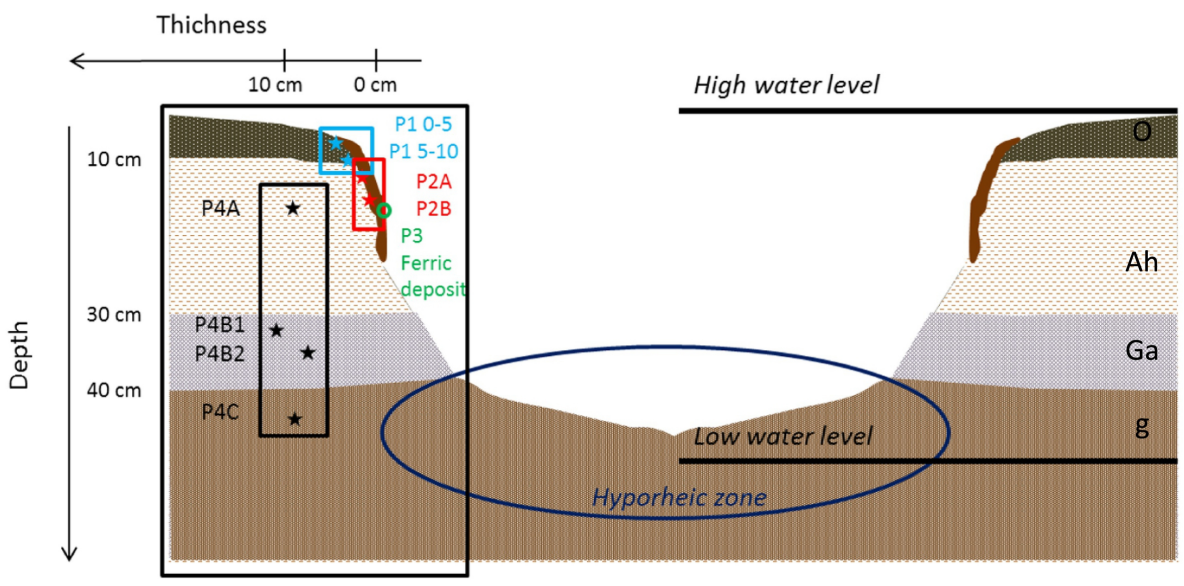

Figure 1 

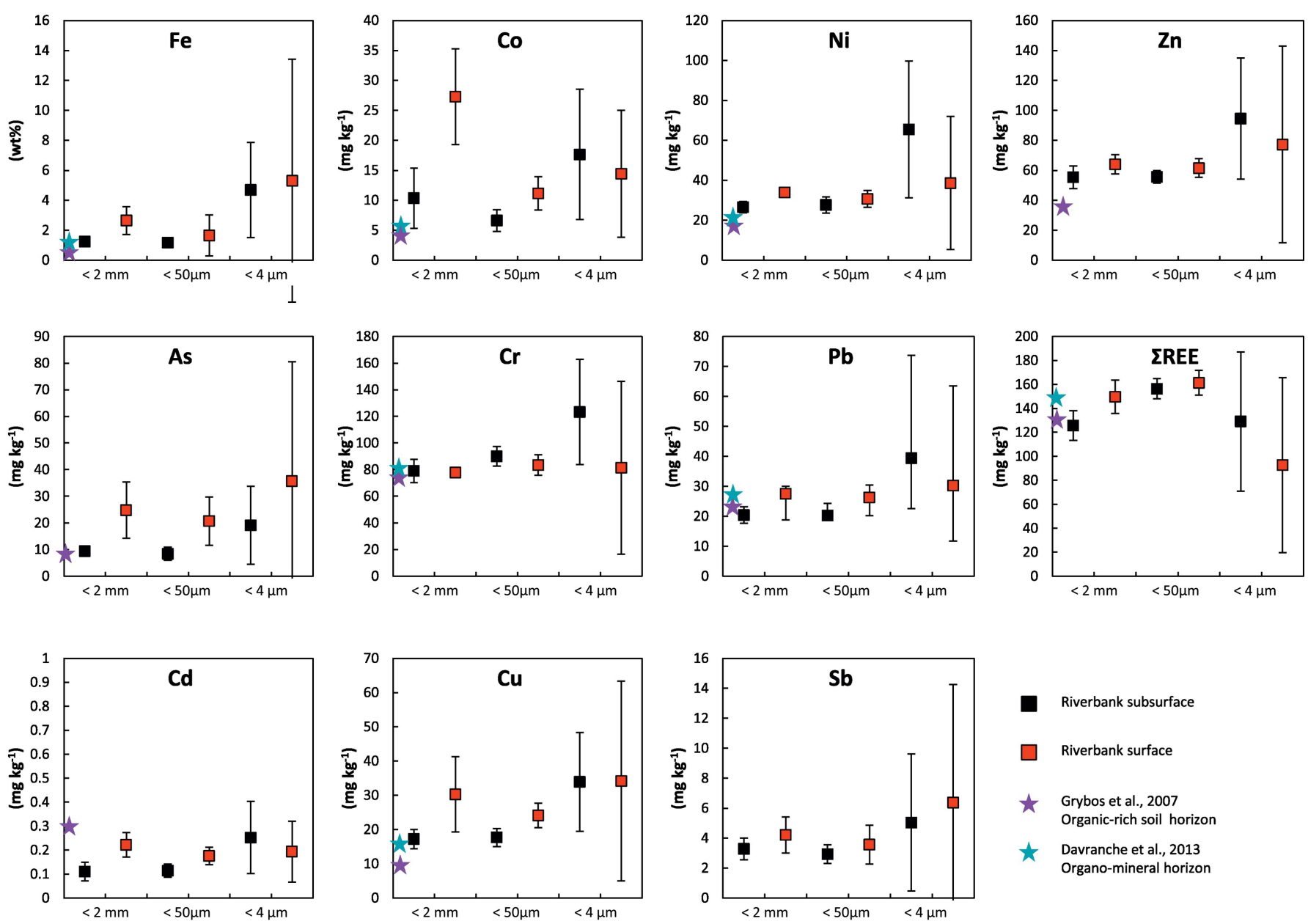

Riverbank subsurface

Riverbank surface

$\downarrow \quad$ Grybos et al., 2007

Organic-rich soil horizon

† Davranche et al., 2013

Organo-mineral horizon

Figure 2 
Variables (F1 and F2 axes : $72.35 \%$ )

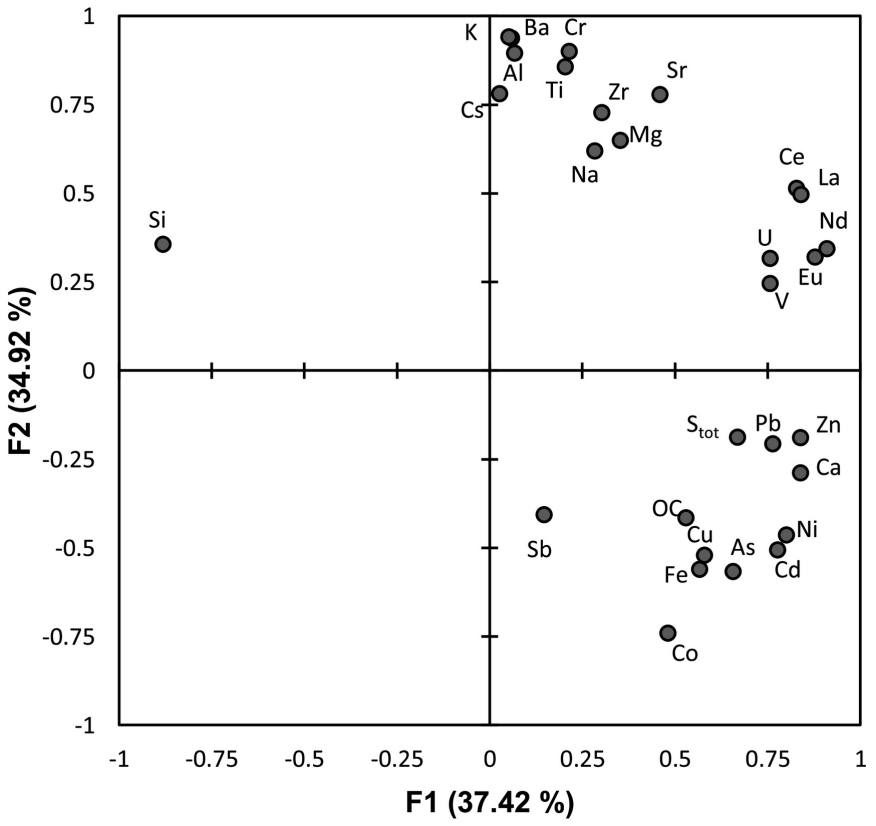

Figure 3 


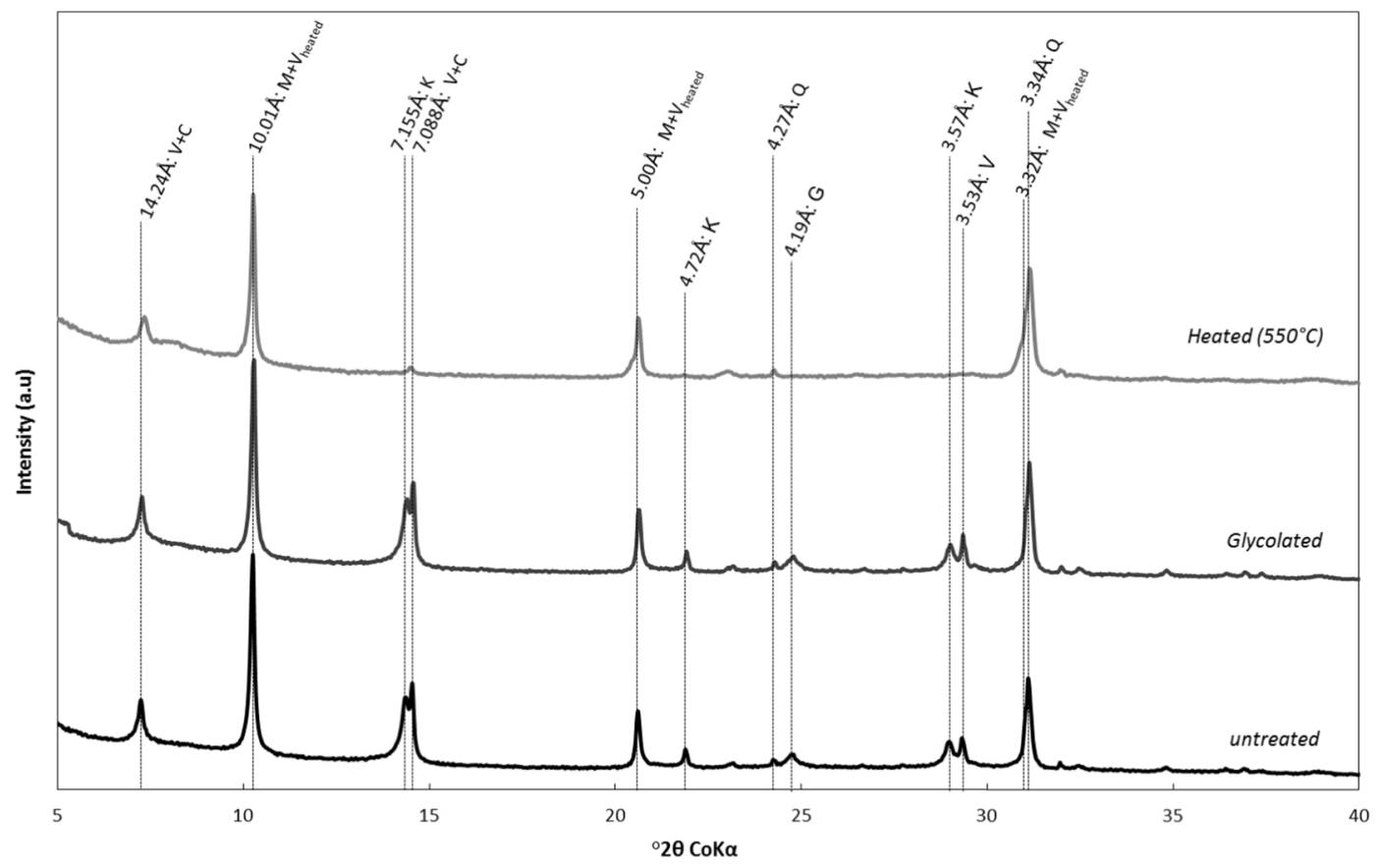

Figure 4 


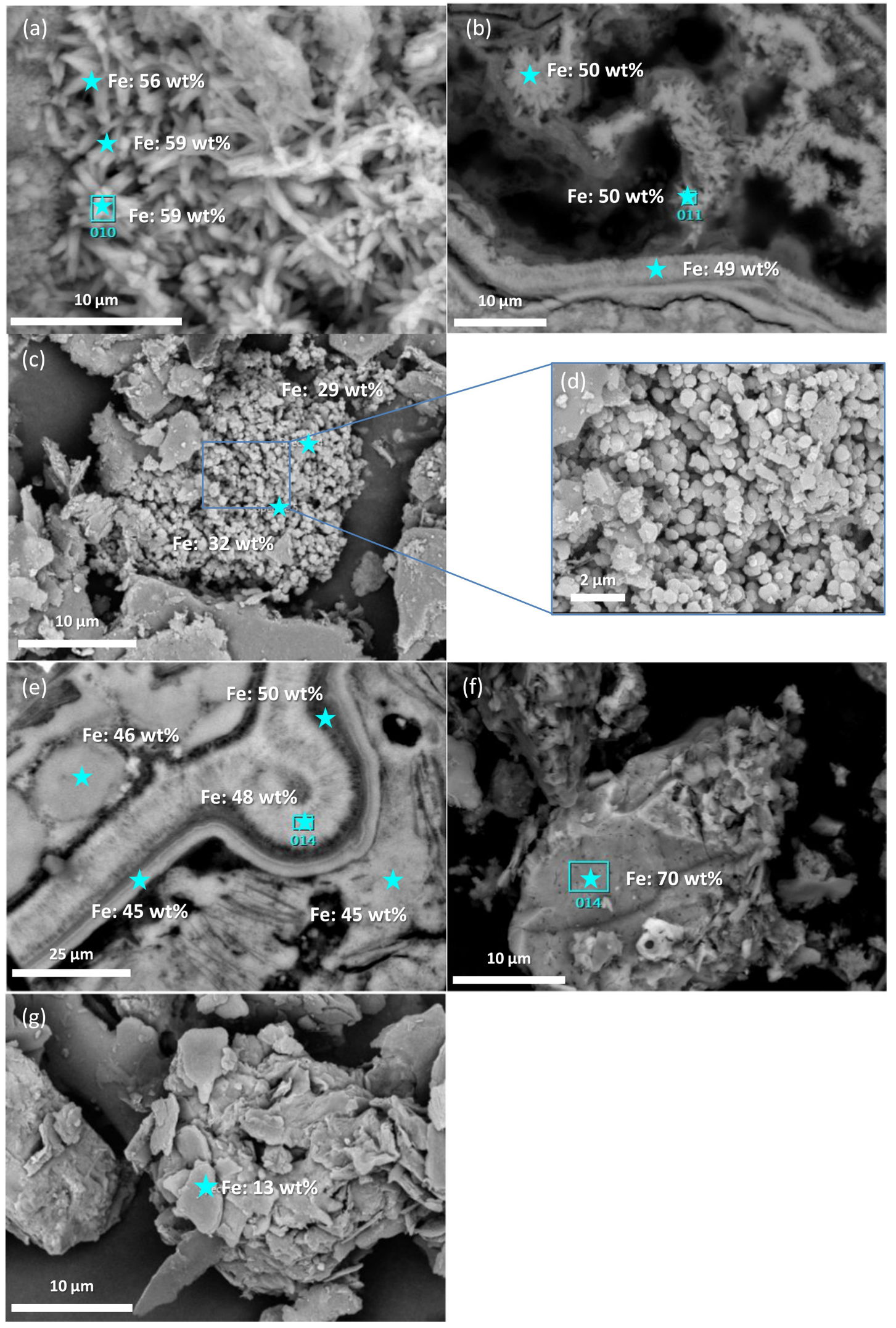




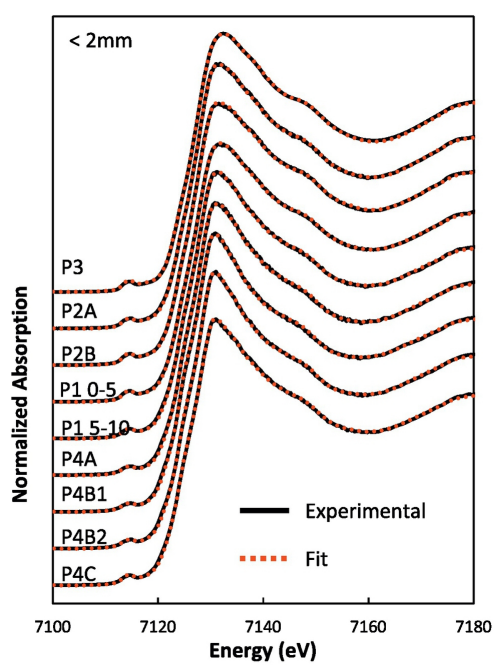

Proportion of Fe species (\%)

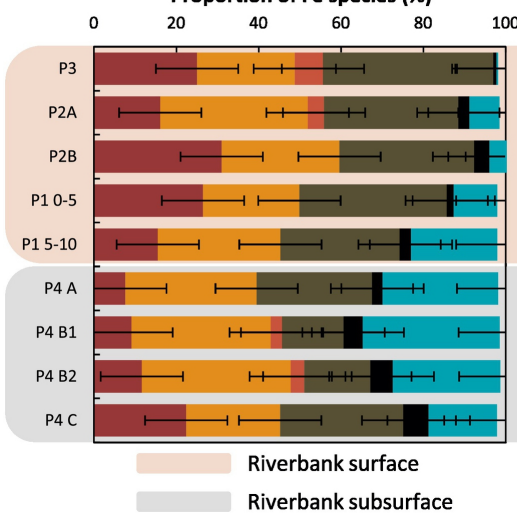

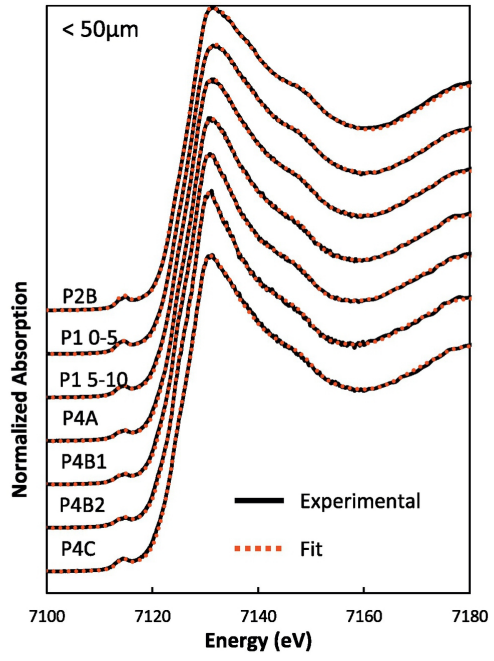

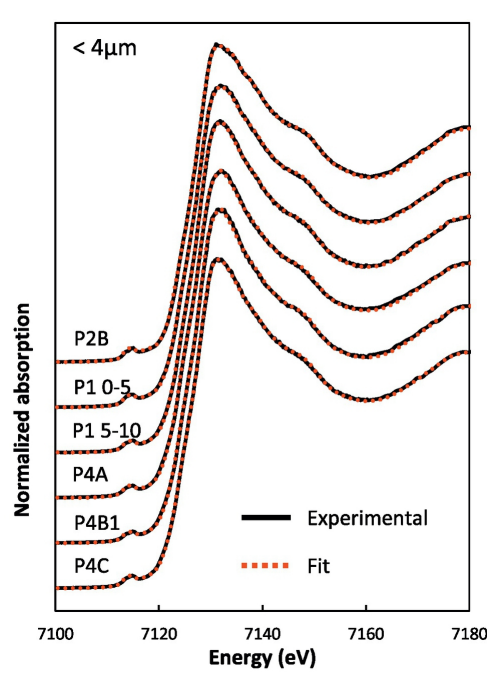

Proportion of Fe species (\%)

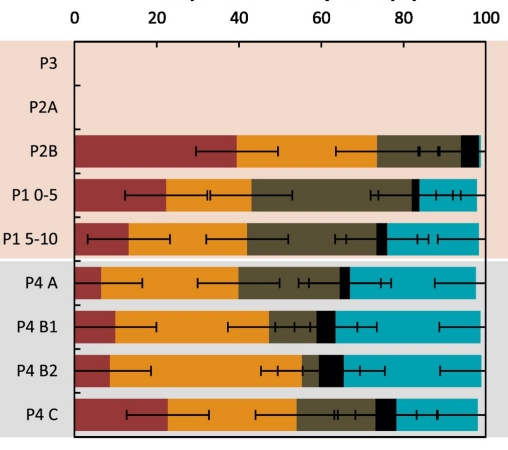

100

Eerrihydrite Goethite Lepidocrocite
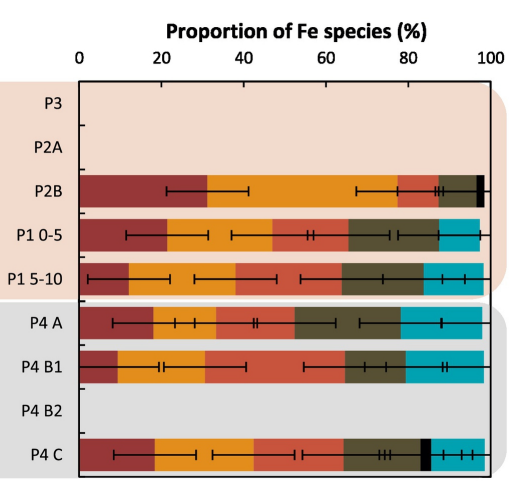

- Fe-OM

Biotite Muscovite

Figure 6 

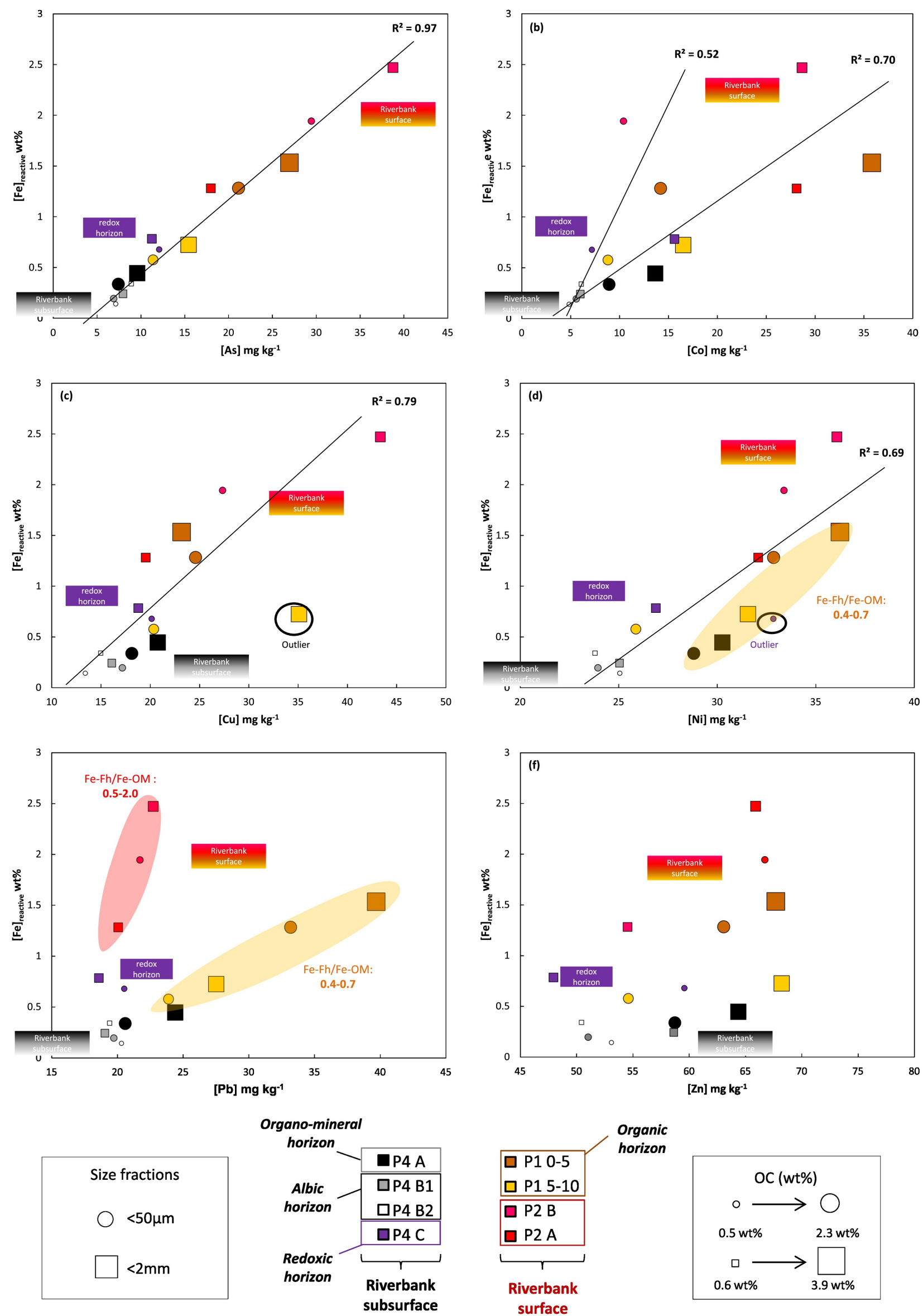
Ferrihydrite and Fe clusters bound to $\mathrm{OM}$
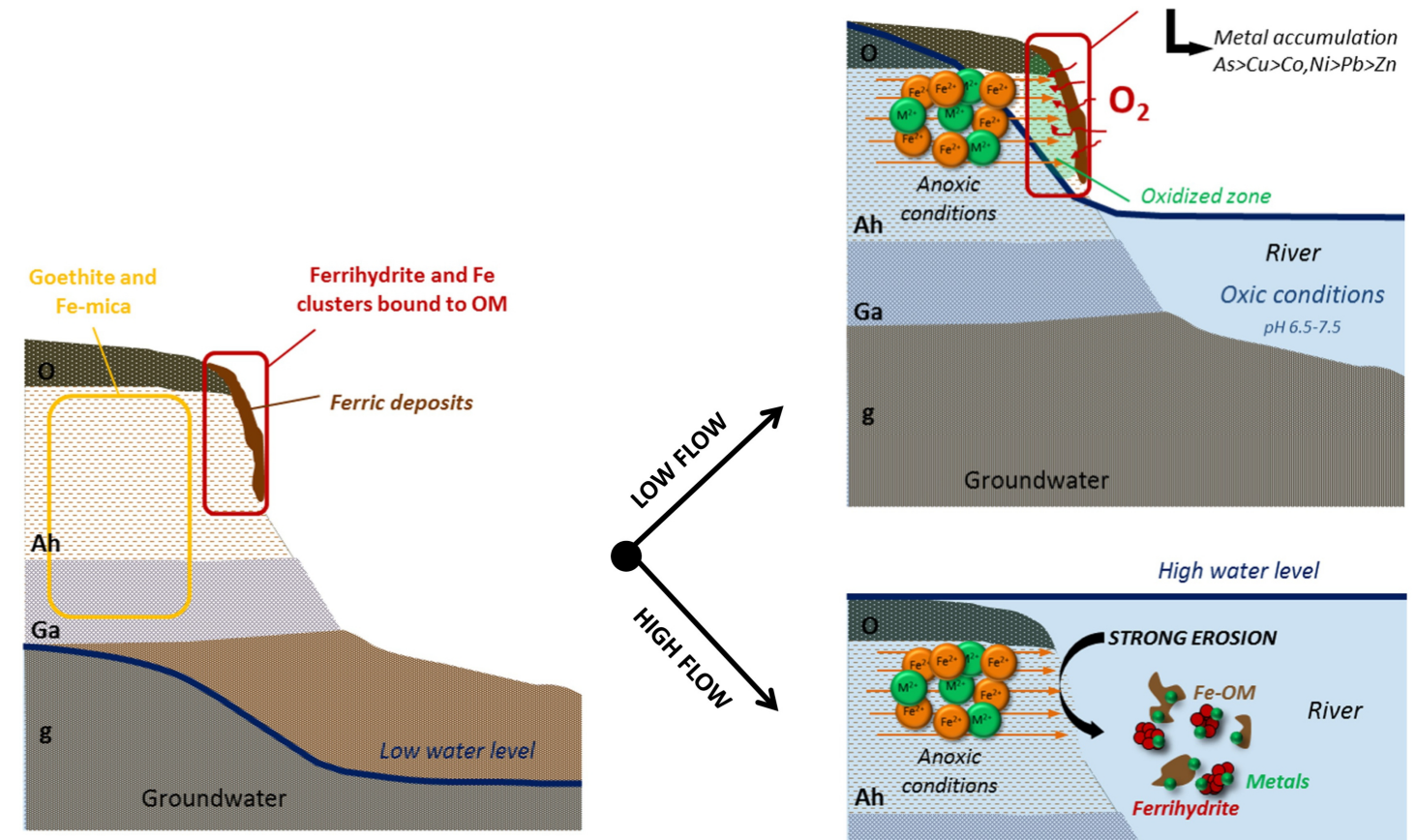

High water level

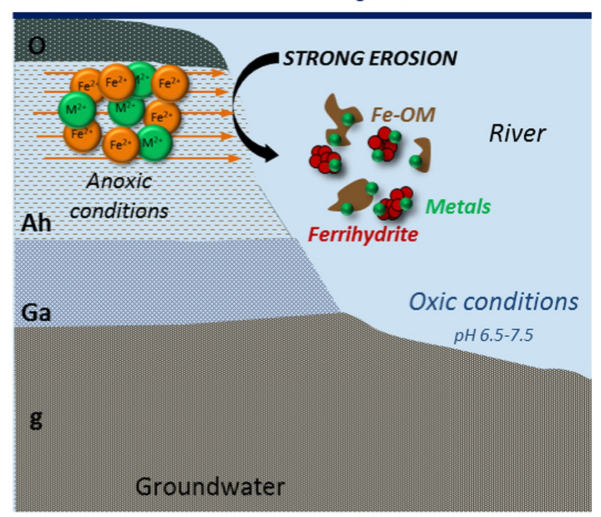

Figure 8 